\title{
GEOLOGIC MAP OF THE KETCHIKAN AND PRINCE RUPERT QUADRANGLES, SOUTHEASTERN ALASKA
}

\author{
By Henry C. Berg, Raymond L. Elliott, and Richard D. Koch
}

\section{INTRODUCTION}

This pamphlet and accompanying map sheet describe the geology of the Ketchikan and Prince Rupert quadrangles in southeastern Alaska (fig. 1). The report is chiefly the result of a reconnaissance investigation of the geology and mineral resources of the quadrangles by the U.S. Geological Survey during 1975-1977 (Berg, 1982; Berg and others, $1978 \mathrm{a}$, b), but it also incorporates the results of earlier work and of more recent reconnaissance and topical geologic studies in the area (fig. 2). We gratefully acknowledge the dedicated pioneering photointerpretive studies by the late William H. (Hank) Condon, who compiled the first 1:250,000-scale reconnaissance geologic map (unpublished) of the Ketchikan quadrangle in the 1950's and who introduced the senior author to the study area in 1956.

Classification and nomenclature in this report mainly follow those of Turner (1981) for metamorphic rocks, Turner and Verhoogen (1960) for plutonic rocks, and Williams and others (1982) for sedimentary rocks and extrusive igneous rocks.

Throughout this report we assign metamorphic ages to various rock units and emplacement ages to plutons largely on the basis of potassium-argon (K-Ar) and lead-uranium ( $\mathrm{Pb}-\mathrm{U})$ (zircon) isotopic studies of rocks in the Ketchikan and Prince Rupert quadrangles (table 1) and in adjacent areas. Most of the isotopic studies were conducted in conjunction with reconnaissance geologic and mineral resource investigations and resulted in the valuable preliminary data that we cite throughout our report. We recognize, however, that our age assignments may be modified in the future as the result of additional isotopic research.

\section{SUMMARY OF GEOLOGY}

This report describes the rocks in the Ketchikan and Prince Rupert quadrangles between the United States-Canada border and long $132^{\circ} 00^{\prime} \mathrm{W}$. The rocks include diverse lithologies that range in age from Ordovician or Silurian to Quaternary. Our investigations show that the rocks are most conveniently described by dividing the quadrangles into three geographic areas (fig. 2), each of which has a distinctive assemblage of rocks that have characteristic lithologies, structure, and metamorphic history.

On the map sheet we present an interpretive geologic section $A-A^{\prime}$, adapted from Berg and others (1978c). Our interpretation is that many of the structural features observed east of Bostwick Inlet (Gravina Island) are manifestations of southwest-vergent nappes and large-scale thrust faults that are intersected by high-angle, mainly strike-slip faults. We also suggest that the thrusts served as channelways for more or less contemporaneous (syntectonic) emplacement of some of the Cretaceous intrusive rocks, whereas other Cretaceous or Tertiary intrusions postdate the thrusts.

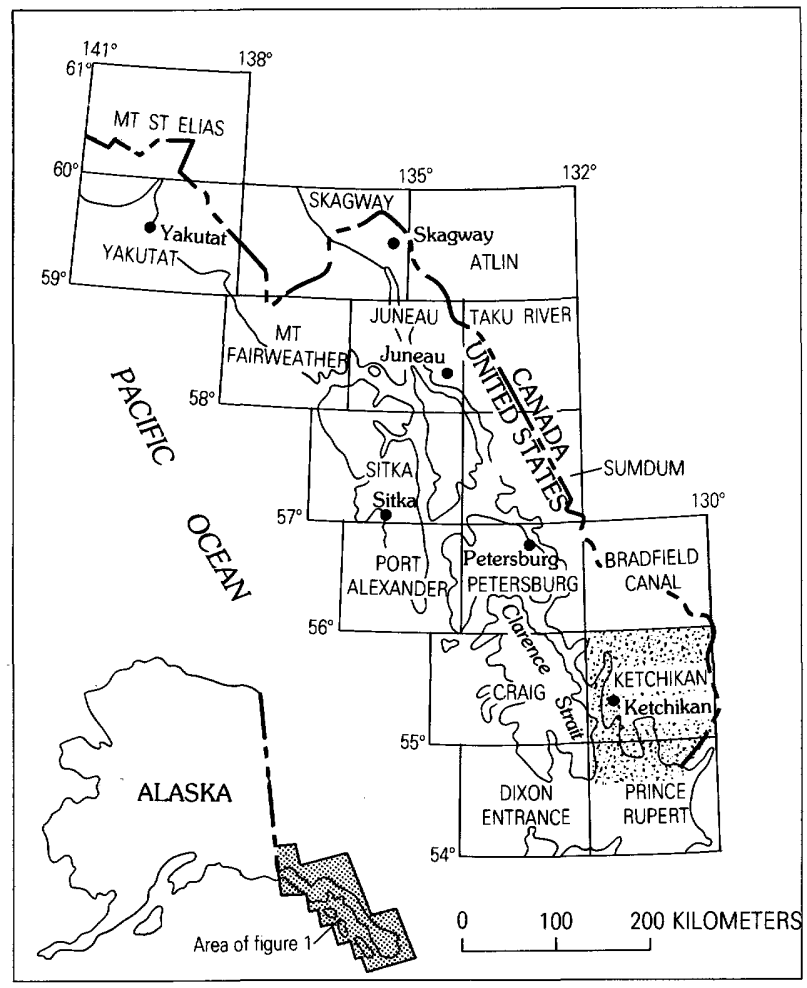

FIGURE 1-Location of Ketchikan and Prince Rupert quadrangles, and area of this investigation (stippled)

\section{PRINCE OF WALES-GRAVINA-ANNETTE-MARY-DUKE ISLANDS AREA}

This area includes Prince of Wales Island east of long $132^{\circ} 00^{\prime} \mathrm{W}$. and the islands bounded by Clarence Strait, Dixon Entrance, Tongass Narrows, and Revillagigedo Channel and makes up about a sixth of the land in the study area. The area contains the most diverse rock types and the most complete sequence of stratified rocks in the Ketchikan and Prince Rupert quadrangles; it also includes the least metamorphosed and least deformed pre-Tertiary rocks in the map area. The bedded rocks range in age from Ordovician or Silurian to Late Jurassic or Cretaceous; the mapped intrusive rocks range in age from Ordovician or Silurian to Oligocene or Miocene. Distinctive units include (a) a Silurian batholith of leucocratic trondhjemite (St) on Annette Island, (b) an Upper Triassic sequence of rhyolite, basalt, and sedimentary rocks (Ksv), and (c) a Cretaceous zoned ultramafic intrusive complex on Duke Island that contains spectacular zones of rhythmically layered 
dunite and peridotite (Kum) (Irvine, 1974). Mineral occurrences (Berg and others, 1978a; 1981, p. 59-70, 97) include (a) barite- and base- and precious-metal bearing volcanogenic sulfide deposits in the Upper Triassic rocks, (b) epithermal veins carrying gold, silver, and other metals in various hostrocks, (c) magmatic titaniferous magnetite deposits in the zoned ultramafic rocks, (d) a base- and precious-metal-bearing skarn deposit in marble and calcsilicate rocks intruded by quartz diorite at McLean Arm on Prince of Wales Island (MacKevett, 1963, p. 99-100), and (e) sparse radioactive minerals in pegmatite dikes near Gardner Bay on Prince of Wales Island (MacKevett, 1963, p. 93-94).

The area is characterized by markedly contrasting metamorphic and structural styles. These contrasting styles are illustrated on Gravina Island (map sheet, section $A-A^{\prime}$; fig. 3 ), where they are separated by a high-angle north-northweststriking fault that divides the island nearly in half. On western Gravina Island the rocks are only slightly regionally metamorphosed, and the dominant regional structures include a northwest-trending open syncline and thrust and high-angle faults that slightly offset rocks as young as Jurassic or Cretaceous. On eastern Gravina Island, the pre-Tertiary rocks are penetratively deformed and regionally metamorphosed to greenschist facies, and the regional structures are southwestoverturned isoclinal folds whose axial surfaces dip moderately northeastward. The isoclinal folds are locally refolded or warped about steeply east(?)-plunging axes, and in places both sets of folds are cut by kink bands associated with vertical cleavage that strikes northeastward. The youngest mapped structure in the area is a strike-slip fault along Tongass Narrows that appears to dextrally offset an Oligocene or Miocene gabbro pluton (Tgb) by about $6.5 \mathrm{~km}$.

\section{REVILLAGIGEDO ISLAND AND CLEVELAND PENINSULA}

The central third of the quadrangle is underlain by diverse plutonic rocks and by multiply deformed and metamorphosed strata that include small outcrop areas of sparsely fossiliferous Permian ( $\mathrm{Pm})$ and Middle Triassic sedimentary and volcanic rocks (Ks), and at least one fault-bounded outcrop area of schist, phyllite, and meta-igneous rocks (SOu) that are intruded by Silurian trondhjemite (Rubin and Saleeby, 1987). By far the most abundant bedded rocks, however, constitute an assemblage of apparently unfossiliferous metamorphosed and deformed strata that we have subdivided into the following four map units according to the lithologies of the protoliths. (1) Locally pyritic dark-gray slate, phyllite, and metagraywacke (metaflysch) intercalated with subordinate green andesitic or basaltic metatuff and rusty-weathering felsic or intermediate metatuff ( $\left.\mathrm{Mz}_{2} \mathrm{~m} \mathrm{~ms}\right)$. Some of the metaflysch is similar to Jurassic or Cretaceous sedimentary rocks on Gravina and Annette Islands. (2) Andesitic or basaltic volcanic and volcaniclastic rocks and subordinate metaflysch ( $\mathrm{MzP}$ zmv). Some of the volcanic rocks consist of relict ferromagnesian-phenocryst porphyry similar to Jurassic or Cretaceous volcanic rocks on Gravina and Annette Islands. (3) Volumetrically minor but locally conspicuous metaconglomerate $\left(\mathrm{Mz}_{2} \mathrm{P}_{2} \mathrm{mc}\right)$. (4) A catchall unit $\left(\mathrm{M}_{2} \mathrm{P}_{2} \mathrm{u}\right)$ consists of several metamorphic rock types too limited in extent to show individually on the geologic map. The assemblage of metamorphosed bedded rocks is intruded by small bodies of metagabbro and metadiorite ( $\mathrm{Mz} \mathrm{P}_{2} \mathrm{mi}$ ) that may be cogenetic with some of the metavolcanic rocks. We have assigned the four units a premetamorphic age of late Paleozoic or Mesozoic because this assignment brackets the age of the oldest (Permian) fossiliferous strata known in this area and of the oldest (Early Cretaceous) isotopically dated plutonic rocks that intrude them. The youngest rocks known in this area are basalt and andesite lava flows, breccia, and tuff (QTV) that mainly coincide with or postdate Quaternary glaciation but may in part be as old as Pliocene.

The oldest radiometrically dated pluton in this area is a dike of Silurian trondhjemite (too small to show on the map sheet) that cuts metamorphosed pre-Devonian rocks near Caamano Point (Rubin and Saleeby, 1987). The oldest dated pluton large enough to show is an Early Cretaceous ultramafic complex (Kum) at Alava Bay. The largest pluton is a radiometrically dated middle Cretaceous quartz diorite and granodiorite batholith $(\mathrm{Kq})$ on northern Revillagigedo Island and adjacent Cleveland Peninsula. Other radiometrically dated Cretaceous plutons include a swarm of mainly un metamorphosed but locally flow-foliated and deformed stocks, diapirs(?), dikes, and sills of epidote- and garnet-bearing and locally plagioclase-porphyritic granodiorite and quartz diorite (Kpg), and an epidote-bearing stock near Moth Bay $(\mathrm{Kg})$ Other intrusive rocks, mainly of known or assumed Cretaceous age, include stocks or domelike sheets of aplite or alaskite (Klg), and several other small ultramafic bodies (Kum). A large radiometrically dated Oligocene or Miocene gabbro complex (Tgb) occurs near Ketchikan.

Regional structures in the pre-Tertiary strata (map sheet, section $A-A^{\prime}$; fig. 3 ) include southwest-overturned to recumbent refolded isoclines that are cut by bedding-plane thrusts and blastomylonite zones and by high-angle faults that postdate the thrusts. Locally on southwestern Revillagigedo Island, the contact between Permian marble and structurally underlying Triassic and possibly younger bedded rocks is a gently to moderately northeast-dipping fault that we interpret as a major thrust zone at or near the base of the marble unit(s). In places, this zone appears to be intruded by Cretaceous plutons. The amount of offset on any of the faults is not known, but our interpretation of the tectonic history of the region (Berg and others, 1972) suggests that their cumulative displacement may be large. The rocks are regionally metamorphosed progressively from greenschist facies on the southwest to amphibolite facies on the north and east. The map sheet and figure 3 show the approximate position of the gradational boundary between the greenschist- and amphibolite-facies rocks in the Ketchikan and Prince Rupert quadrangles. The minerals and textures resulting from this regional metamorphism, which we interpret to be middle or Late Cretaceous in age, are overprinted by contact metamorphism as intense as hornblendehornfels facies near the contacts of the Cenozoic and some of the Mesozoic plutons. Feather schist or "garbenschiefer" (Turner and Verhoogen, 1960, p. 649), a metamorphic rock distinguished by locally conspicuous feathery crystal aggregates of actinolite in a matrix of garnet-bearing silvery muscovite schist, is widespread on central and southeastern Revillagigedo Island; its distinctive mineralogy and texture suggest complex metamorphism of a bedded unit that was significantly different in original composition from that of the adjoining strata.

Mineral occurrences that have been productive or extensively explored include massive lead- and zinc-sulfide deposits and auriferous quartz veins in the metasedimentary and metavolcanic units, a stibnite (antimony) vein in marble near Caamano Point, and titaniferous magnetite in the ultramafic complex at Alava Bay (Berg and others, 1978a, 1981).

\section{PORTLAND PENINSULA}

The east half of the Ketchikan-Prince Rupert study area is a peninsula, bounded by (eastern) Behm Canal, Revillagigedo Channel, and Portland Canal, that we informally call "Portland peninsula". The youngest consolidated rocks known on Portland peninsula correlate with the Tertiary or Quaternary 


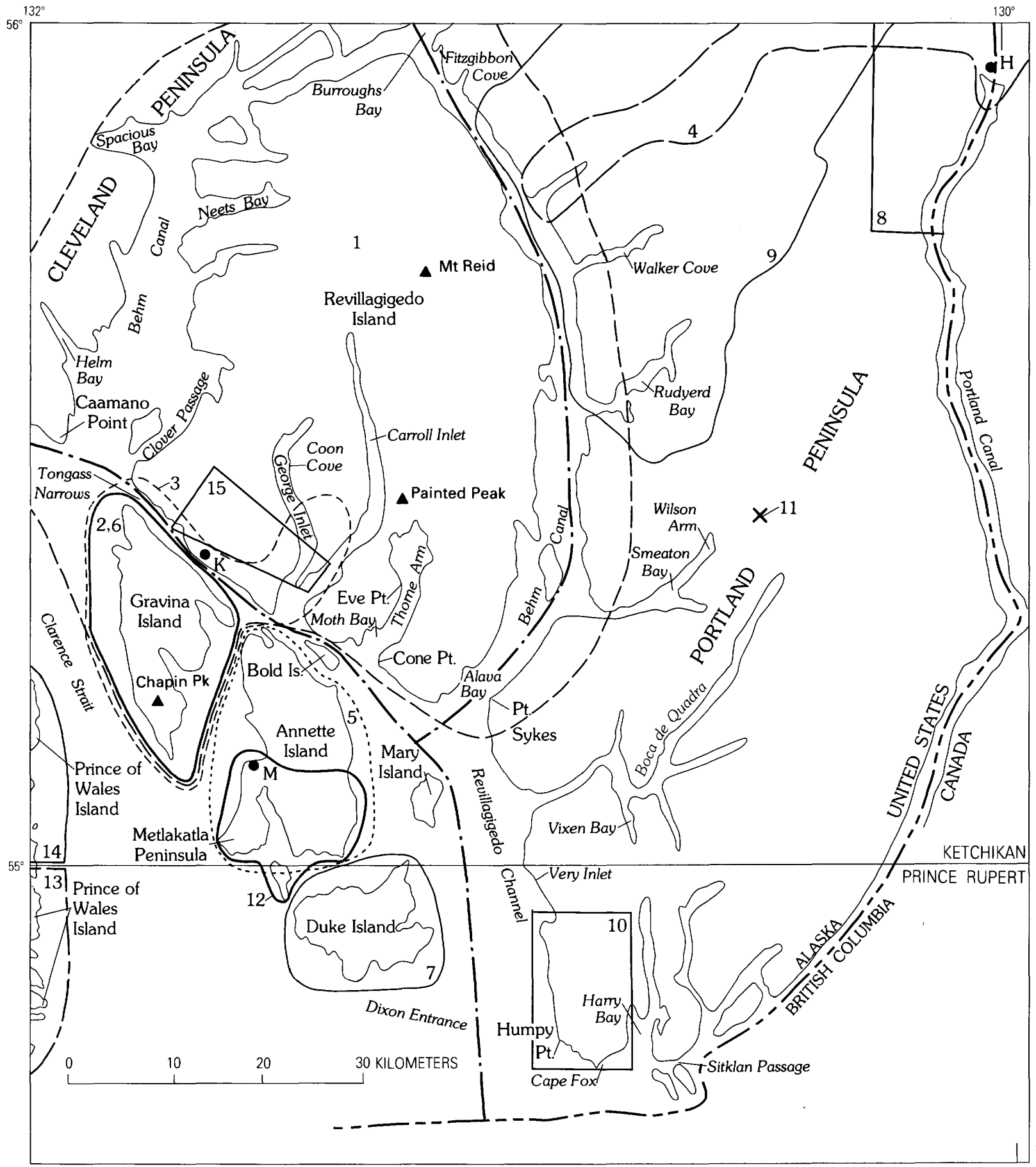

FIGURE 2-Ketchikan quadrangle and northern part of Prince Rupert quadrangle, showing areas described in selected geologic reports: 1, Brooks (1902); 2, Smith (1915); 3, Chapin (1918); 4, Buddington (1929); 5, Berg (1972); 6. Berg (1973); 7, Irvine (1974); 8, Smith (1977); 9, Berg and others (1977); 10, Koch and others (1977); 11, Elliott and others (1976) and Hudson and others (1979); 12, Gehrels and others (1984); 13, MacKevett (1963) and Gehrels and Saleeby (1987); 14, geology extrapolated from Eberlein and others (1983); 15, Koch and Elliott (1984). H, Hyder; K, Ketchikan; M, Metlakatla. Dot-dash lines outline the three geographic areas described in "Summary of Geology". 


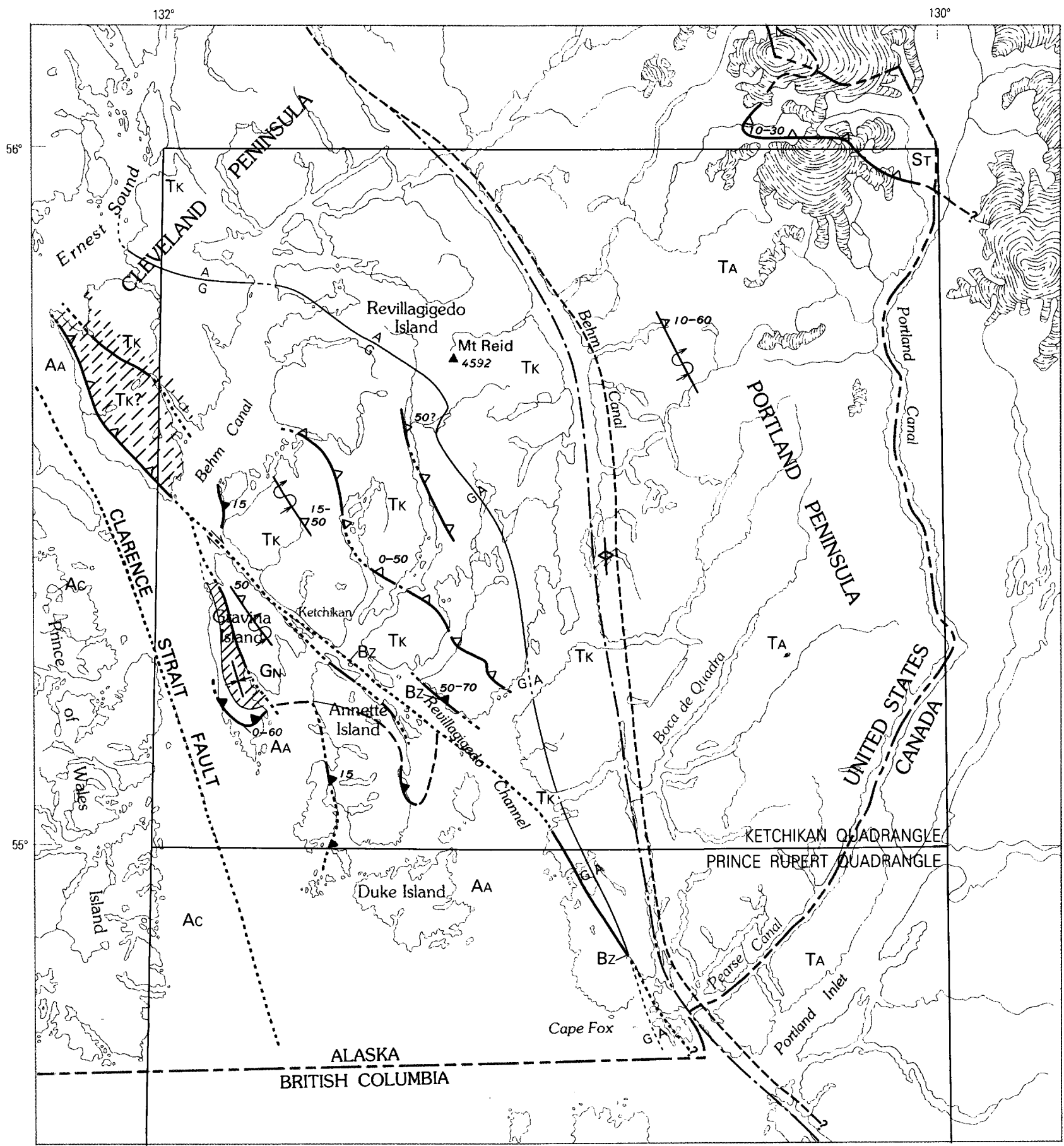

$\stackrel{10}{\square+L 1} \stackrel{0}{1} \quad 10 \quad 20$ KILOMETERS

FIGURE 3-Interpretive map showing tectonostratigraphic terranes and structural framework of the Ketchikan and Prince Rupert quadrangles. Plutons not shown. Base map from the National Atlas of the United States, U.S. Geological Survey, 1970. 


\title{
EXPLANATION FOR FIGURE 3
}

\author{
Tectonostratigraphic terrane-Queried where assumed
}

GN/7 Gravina-Nutzotin belt-Unpatterned, basement not exposed. Solid-line
pattern shows distribution of Gravina-Nutzotin belt depositionally
overlying Alexander terrane
overlying Alexander terrane

\begin{tabular}{|l|}
\hline$A C$ \\
\hline$A A$ \\
\hline$T K$
\end{tabular}

Alexander terrane

Craig subterrane

Annette subterrane

Taku terrane-Dashed line pattern shows distribution of strata that are possibly coeval with those in Gravina-Nutzotin belt. Extent of thes $\epsilon$ rocks in Taku terrane is unknown

\begin{tabular}{|l|}
\hline$T_{A}$ \\
\hline$S_{T}$ \\
\hline
\end{tabular}

Tracy Arm terrane

Stikine terrane

Contact-Dotted where concealed

High-angle fault-Dotted where concealed. Arrows show relative movement. May coincide in strike with reverse or thrust fault

Thrust fault-Sawteeth on upper plate; dotted where concealed. May coincide in strike with high-angle fault

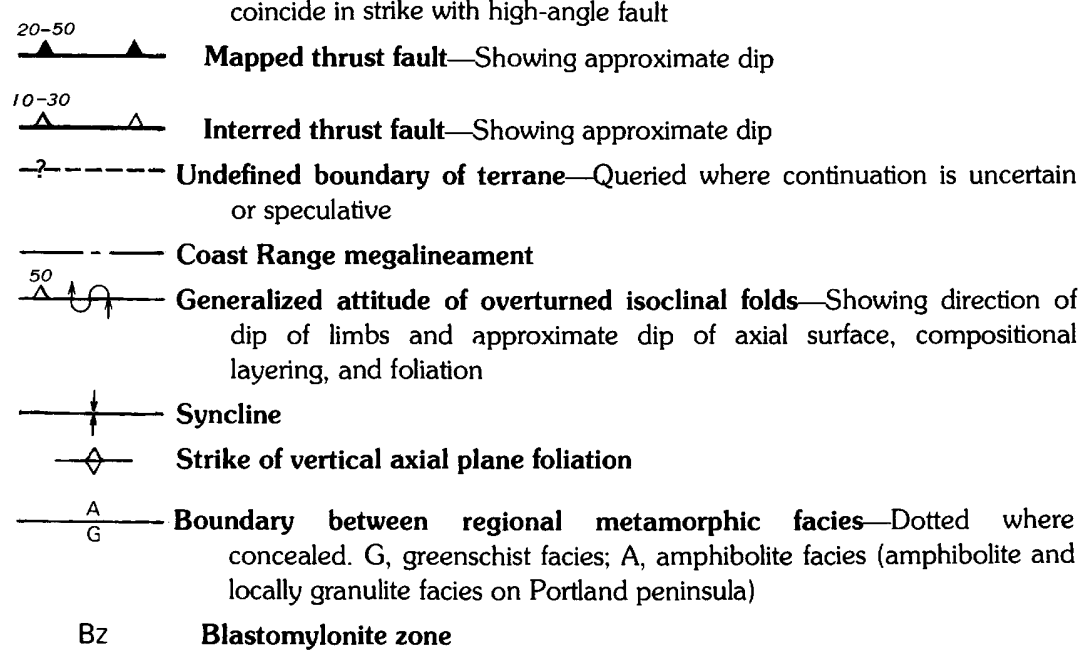

basalt and andesite on Revillagigedo Island (QTV). Except for small outcrop areas of these volcanic rocks, most of the peninsula is underlain by a complex of Mesozoic and Cenozoic plutons that enclose metamorphic screens and roof pendants of problematic premetamorphic age. This plutonic-metamorphic complex is fringed on the west and southwest by metamorphosed upper Paleozoic or Mesozoic bedded rocks, by undivided Ordovician or Silurian bedded and intrusive rocks, and by Paleozoic, Mesozoic, and Cenozoic plutons. At the northeast corner of the map area the complex is bounded by recrystallized lower Mesozoic and possibly upper Paleozoic intrusive and bedded rocks ( $\mathrm{kt}, \mathrm{MzP}_{\mathbf{2}} \mathrm{vs}$ ). Parts or all of the plutonicmetamorphic complex have been variously termed the "Coast Range batholith" (Buddington and Chapin, 1929, p. 173253), "Coast plutonic complex" (Roddick and Hutchison, 1974), "Central gneiss complex" (Hutchison, 1970, 1982), "Coast plutonic-metamorphic complex" (Brew and Ford, 1984), and several other variants of those terms. Some work- ers have applied those terms to rocks beyond the geographic limits of the plutonic-metamorphic complex as defined in our report. In our report, the complex is bounded on the west by the western contacts of three map units: foliated quartz diorite (TKfq) and granodiorite (TKfg), and paragneiss (MzPyp). The southeast boundary is beyond the limits of the Ketchikan and Prince Rupert quadrangles in Alaska. The complex does not include the recrystallized lower Mesozoic and upper Paleozoic rocks at the northeast corner of the map area.

The plutonic-metamorphic complex is a heterogeneous group of massive to foliated or gneissic batholiths, stocks, and smaller plutons and regionally metamorphosed amphiboliteand possibly locally granulite facies stratified rocks (MzPz) that form septa, screens, roof pendants, and xenoliths within or between the plutons. According to our radiometric age data, the plutons were emplaced during Early Cretaceous, Late Cretaceous or Paleocene, Eocene, and Oligocene or Miocene time. Their composition ranges from granite to gab- 
bro; the most abundant rock type is foliated granodiorite $(\mathrm{TKfg})$. Not shown on the map are numerous Oligocene or younger lamprophyre (Smith, 1973) and quartz porphyry (Hudson and others, 1979) dikes. The premetamorphic age of the stratified rocks has not yet been conclusively determined by isotopic methods. We assign them a Paleozoic or Mesozoic age to bracket the ages of (a) probably correlative, isotopically dated Paleozoic or older metamorphosed bedded rocks in neighboring British Columbia (Hutchison, 1982, p. 23-24) and (b) the oldest isotopically dated (Early Cretaceous) plutons known to intrude them. The isotopically determined age of metamorphism of the foliated plutonic and bedded rocks on Portland peninsula is Eocene (Smith and Diggles, 1981, p. 2 $3)$. Structural trends, isograds, and lithologic units strike northwest to north; foliation varies in regional dip from vertical and steeply westward-dipping in many places along Behm Canal to gently to moderately northeastward dipping on central Portland peninsula (map sheet, section $A-A^{\prime}$, fig. 3 ).

West and southwest of the plutonic-metamorphic complex is a wedge-shaped outcrop belt of regionally metamorphosed greenschist- to amphibolite-facies. Near plutons such as the one near Point Sykes $(\mathrm{Kgq})$, this metamorphism is locally overprinted by contact metamorphism that in places reaches hornblende hornfels facies. Feather schist is widespread. The east limit of this belt is the west boundary of the plutonicmetamorphic complex as herein defined. On the west and north the ourcrop belt is terminated by Revillagigedo Channel and Behm Canal, but our mapping indicates that correlative rocks also occur on parts of Revillagigedo Island and on Annette and neighboring islands. The outcrop belt consists of two tracts separated by a northwest-trending linear fault zone that extends from Harry Bay to beyond Kah Shakes Cove. The rocks northeast of the fault are mainly phyllite and schist ( $\left.\mathrm{M}_{2} \mathrm{P}_{2} \mathrm{a}, \mathrm{Mz}_{\mathrm{z}} \mathrm{u}\right)$ derived from graywacke flysch, from mafic, intermediate, and subordinate felsic volcanic and volcaniclastic rocks, and from small amounts of limestone $(\mathrm{m})$. Very sparse objects, doubtfully identified as crinoid disks implying a late Paleozoic age (Berg and Cruz, 1982) occur in marble layers (m) along Very Inlet. These objects, coupled with our mapping of lithically similar rocks on southern Revillagigedo Island, lead us to assign these marbles, and associated rocks in this tract a premetamorphic age of late Paleozoic or Mesozoic. Mapped plutonic rocks in this tract include granodiorite $(\mathrm{Kgq})$ stocks that are isotopically dated and provisionally of Cretaceous age and elongate bodies of trondhjemitic pegmatite (TKp) that are of inferred Late Cretaceous or Tertiary emplacement age. Southwest of the fault the rocks consist mainly of a metamorphosed Silurian trondhjemite stock (Smt) that intrudes metamorphosed bedded and intrusive rocks (SOu) similar to Ordovician or Silurian rocks mapped on Annette, Mary, and Duke Islands.

About $30 \mathrm{~km}^{2}$ of the northeasternmost corner of the Ketchikan quadrangle is underlain by recrystallized Triassic plutonic rocks $(\mathrm{k} t)$ and by recrystallized Triassic or older volcanic and sedimentary rocks $\left(\mathrm{M}_{\mathrm{z}} \mathrm{z} v \mathrm{vs}\right)$. These rocks, which were locally cataclastically deformed during Mesozoic or early Cenozoic time and then intruded by Eocene plutons, are notably less deformed and metamorphosed than those of the plutonic-metamorphic complex to the southwest. We infer that the boundary between these two contrasting assemblages is a moderately northeast-dipping thrust zone that subsequently has been intruded and largely obliterated by the Eocene plutons (map sheet, section $A-A^{\prime}$; fig. 3 ; Berg and others, 1977, p. 29).

In 1987 the most commercially attractive mineral deposit on Portland peninsula is a large porphyry molybdenum lode at Quartz Hill (fig. 2, area 11; Hudson and others, 1979).
Other mineral deposits that have been explored by private interests include (a) another porphyry molybdenum occurrence on the north shore of the mouth of Borroughs Bay, (b) gold, silver, tungsten, and base-metal veins and disseminated deposits in the Triassic or older volcanic and intrusive rocks near Hyder, (c) base-metal massive sulfide deposits in the metamorphosed bedded rocks southwest of Smeaton Bay and near Humpback Lake, and (d) copper-, zinc-, and silver-bearing sulfide veins and disseminations in paragneiss at Walker Cove (Berg and others, 1977, 1981).

\section{TECTONOSTRATIGRAPHIC TERRANES AND STRUCTURAL FRAMEWORK}

Regional tectonic and biostratigraphic investigations (Berg and others, 1972, 1978c; Monger and Berg, 1985) show that the pre-Cenozoic strata in the Ketchikan and Prince Rupert quadrangles can be interpreted as constituting five, mainly fault-bounded assemblages (map sheet, section $A-A^{\prime}$; fig. 3 ), each characterized by its own distinctive stratigraphy and tectonic history. Northeastward from Prince of Wales Island these tectonostratigraphic assemblages are known, respectively, as the Alexander terrane, comprising the Craig and Annette subterranes; the Gravina-Nutzotin belt; the Taku terrane; the Tracy Arm terrane; and the Stikine terrane.

\section{ALEXANDER TERRANE}

The Alexander terrane constitutes most of the Alexander Archipelago of southeastern Alaska and parts of neighboring British Columbia and Yukon Territory. It comprises upper Precambrian to Triassic strata and is composed of three allochthonous, originally disjunct or otherwise distinctive crustal blocks named the Admiralty, Craig, and Annette subterranes (Berg and others, 1978c). The Ketchikan-Prince Rupert study area contains a small part of the Craig subterrane and all of the Annette subterrane.

Craig subterrane

The Craig subterrane is distinguished by a relatively complete and undeformed sequence of Ordovician to Permian clastic, carbonate, and volcanic strata, by diverse plutonic rocks, and by a pre-Middle Ordovician metamorphic complex (Wales Group) that may be as old as Precambrian (Gehrels and Saleeby, 1987, p. 126-127). Recent mapping and geochronologic studies (Gehrels and Saleeby, 1987; Gehrels and others, $1983 \mathrm{~b}, \mathrm{c})$ show that the southern part of the subterrane is underlain by an Ordovician or Silurian volcanoplutonic complex of diorite and trondhjemite and cogenetic volcanic and volcaniclastic rocks and that this basement complex is in fault contact with Wales Group metabasite and metacarbonate rocks. In the Ketchikan and Prince Rupert quadrangles the Craig subterrane occurs west of Clarence Strait, where it is exposed only on the easternmost coastal fringes of southern Prince of Wales Island, and where it consists of Devonian(?) and older Paleozoic bedded, intrusive, and metamorphic rocks.

Annette subterrane

The Annette subterrane is distinguished by (a) a heterogeneous assemblage of Ordovician or Silurian, Silurian, and Devonian intrusive, extrusive, clastic, and carbonate rocks on or near Annette and Gravina Islands and on southwestern Cleveland Peninsula (Rubin and Saleeby, 1987), (b) the absence of any known post-Middle Devonian Paleozoic strata, and (c) Upper Triassic rhyolite, basalt, clastic, and carbonate rocks. The youngest pre-Cenozoic stratigraphic unit assigned to the Annette subterrane is the Upper Triassic Chapin Peak Formation.

These rocks record several episodes of magmatic-arc and possibly rift-related volcanism, sedimentation, and intrusion that began at least as long ago as early Paleozoic time. They 
also record a history of deformation and metamorphism that, depending on the age and location, varies from repeated penetrative folding and polymetamorphism as intense as amphibolite and hornblende-hornfels facies to relatively simple folding accompanied by the development of slaty cleavage and only slight recrystallization.

Recent investigations by Gehrels and others (1987, $1983 \mathrm{~b}, \mathrm{c})$ show that the Annette subterrane contains an Ordovician or Silurian volcanoplutonic complex similar to the one in the Craig subterrane. These data suggest that the two subterranes may have been in related tectonic environments in Ordovician or Silurian time, but the marked differences in their Devonian and later Paleozoic history supports their distinction as separate subdivisions of the Alexander terrane.

The Annette subterrane is separated from the Craig subterrane by the Clarence Strait fault, and from the Taku terrane by mapped or inferred faults, along which the rocks locally are metamorphosed to blastomylonite (fig. 3). Rubin and Saleeby (1987) interpret the Alexander (Annette)-Taku terrane boundary as a tectonic zone of imbricate east-dipping thrust sheets with a total structural thickness of over $15 \mathrm{~km}$. On Annette and Gravina Islands, the contact of the Annette subterrane with the Gravina-Nutzotin belt is an unconformity locally cut by normal and reverse faults.

\section{GRAVINA-NUTZOTIN BELT}

The Gravina-Nutzotin belt (map sheet, section $A-A^{\prime}$; fig. 3) comprises Middle(?) Jurassic to Lower Cretaceous flysch, andesitic or basaltic volcanic rocks, and subvolcanic dioritic to ultramafic plutons. This assemblage is interpreted as the remnants of a late Mesozoic volcanic arc (Berg and others, 1972). On western Gravina Island, bedded rocks assigned to the belt are only slightly folded and recrystallized; on eastern Gravina Island and on Annette Island, they are regionally metamorphosed to greenschist facies and folded into southwest-overturned, locally refolded isoclines whose axial surfaces dip moderately northeast. On the southwest, the Gravina-Nutzotin belt is in locally faulted stratigraphic contact with the underlying Annette subterrane. On the northeast, the extent and distribution of rocks of the Gravina-Nutzotin belt are not yet known. The belt is separated from the Taku terrane by faults (Rubin and Saleeby, 1987), along which the rocks locally are metamorphosed to blastomylonite (fig. 3).

\section{TAKU TERRANE}

The Taku terrane is a possibly polygenetic assemblage of multiply deformed and metamorphosed strata that contain sparse fossils of Permian and Middle or Late Triassic age, as well as undated metaflysch and andesitic or basaltic metavolcanic rocks that may in part correlate with Jurassic or Cretaceous strata in the Gravina-Nutzotin belt (fig. 3). The key stratigraphic sequences of the terrane include (a) a thick sequence of upper Paleozoic basaltic tuff and agglomerate that occurs in this terrane mainly north of the Ketchikan and Prince Rupert quadrangles and that is not known in any of the other terranes (Berg and others, 1978c) and (b) at least one unit of metaconglomerate $\left(\mathrm{MzP}_{\mathrm{z}} \mathrm{mc}\right)$ that contains prominent relict roundstones of trondhjemite or leucocratic quartz diorite and quartzite in the Ketchikan-Prince Rupert study area. Within the study area, the key basaltic volcanic sequence may be represented by the intermediate to mafic metavolcanic rocks (MzPzmv) on Revillagigedo Island and Clevelend Peninsula and by amphibolite ( $\left.M_{2} P_{2} a\right)$ on western and southwestern Portland peninsula.

The premetamorphic age(s) of the metaconglomerate may be the key to the tectonic history of the Taku terrane. At Gnat Cove it may grade into upper Paleozoic crinoidal marble, and at Back Island it is intercalated with metaflysch similar to the flysch in the Gravina-Nutzotin belt; these relations suggest that metaconglomerate occurs in at least two stratigraphic horizons. The trondhjemite clasts in the metaconglomerate are compositionally similar to the Silurian trondhjemite plutons on Annette and Gravina Islands (St) and near Cape Fox (Smt) on Portland peninsula, which are different from any other plutons known in the Ketchikan and Prince Rupert quadrangles, and which may have been the source of the clasts. If the premetamorphic age of the trondhjemite-clast metaconglomerate that may grade into upper Paleozoic marble also is late Paleozoic and if the source of the clasts is the Silurian plutons, then the metaconglomerate may record structural juxtaposition (amalgamation) at least of the southern Alexander and Taku terranes by late Paleozoic time. Furthermore, if the premetamorphic age of the metaconglomerate that is intercalated with the metaflysch is late Mesozoic, then the metaconglomerate may record juxtaposition of the Alexander terrane, Gravina-Nutzotin belt, and Taku terrane at that time.

The stratigraphic base of the Taku terrane is unknown. If we assume an external provenance for the trondhjemite clasts in the metaconglomerate, then there is no faunal, lithologic, or stratigraphic evidence of rocks older than late Paleozoic lying stratigraphically beneath the terrane.

The west boundary of the Taku terrane is a zone of complex faults, along which the rocks locally are metamorphosed to blastomylonite (fig. 3). Rubin and Saleeby (1987) interpret this boundary as a tectonic zone of imbricate east-dipping thrust sheets with a total structural thickness of over $15 \mathrm{~km}$. In the study area, the northeast boundary is along the west contacts of the paragneiss ( $\mathrm{MzP} \mathrm{z}$ ) and foliated granodiorite (TKfg) and quartz diorite (TKfq) units. Beyond the limits of the study area, the foliated quartz diorite (tonalite) apparently coalesces into a persistent zone of northwest- or north-trending sills (Brew and Ford, 1981) that probably were emplaced along a now-obliterated Mesozoic suture that bounded the Taku and Tracy Arm terranes (map sheet, section $A-A^{\prime}$; Berg and others, 1978c; Brew and Morrell, 1979). This boundary also is spatially related to the Coast Range megalineament (fig. 3; Brew and Ford, 1978), an enigmatic topographic, structural, and geophysical feature that appears to have been the western limit of large-scale regional uplift of Portland peninsula beginning in Early Tertiary time (Hutchison, 1970, p. 396; 1982, p. 88-90, 96-97).

Field studies in 1981 (Monger and Berg, 1985) suggest that the Taku terrane in southeastern Alaska comprises at least three distinctive stratigraphic assemblages whose northwesttrending boundaries and internal lithologic trends obliquely intersect the west and east boundaries of the terrane at angles as large as $40^{\circ}$. The stratigraphic differences suggest that the Taku terrane may actually consist of structurally juxtaposed, originally disjunct crustal blocks, and the truncation of their trends supports the interpretation that the terrane is bounded by partly obliterated regional faults.

\section{TRACY ARM TERRANE}

The Tracy Arm terrane (map sheet, section $A-A^{\prime}$; Berg and others, 1978c) consists of regionally metamorphosed to amphibolite- and locally granulite-facies stratified rocks and minor ultramafic bodies. These rocks form a discontinuous belt of roof pendants, screens, and xenoliths enclosed by Cretaceous or Tertiary plutons, and they lie within or east of a zone of nearly continuous sills of quartz diorite (tonalite) that has been traced for at least the length of southeastern Alaska (Brew and Ford, 1981). In the Ketchikan-Prince Rupert study area, this terrane occurs on Portland peninsula and consists of sequences of pelitic and quartzofeldspathic paragneiss and 
schist and minor marble and amphibolite. These rocks are much less abundant than the massive to gneissic plutons that enclose them.

The premetamorphic stratigraphy of the Tracy Arm terrane is unknown. Preliminary strontium isotopic studies ol granitic rocks on Portland peninsula (J.G. Arth, written commun., 1978) suggest that Precambrian or lower Paleozoic continental crustal rocks are not present. On the other hand, nearby in British Columbia, $\mathrm{Pb}-\mathrm{U}$ (zircon) isotopic age determinations on paragneiss that is presumably correlative with that on Portland peninsula suggest Precambrian, older Paleozoic, and pre-Permian ages (Hutchison, 1982, p. 23-24). Still other investigations in British Columbia (Woodsworth and others, 1983 , p. 10) suggest Late Triassic or younger Mesozoic permetamorphic ages for some of the strata in the Tracy Arm terrane. These apparently conflicting data, coupled with the wide variation in premetamorphic lithologies in the Tracy Arm terrane in southeastern Alaska, suggest that the Tracy Arm terrane, like the Taku terrane, may actually comprise several originally disjunct tectonostratigraphic assemblages.

In the Ketchikan-Prince Rupert study area the southwest limit of the Tracy Arm terrane is along the west contacts of the paragneis 3 and foliated granodiorite and quartz diorite units, as discussed in the foregoing description of the Taku terrane. The northeast limit of the terrane is along a postulated zone of thrust faults that has been intruded by Eocene plutons (Berg and others, 1977, p. 29). In the northeastern part of the Ketchikan quadrangle, this zone appears to dip north or east and to thrust rocks of the Tracy Arm terrane beneath those of the Stikine terrane. Thrust faults that separate rocks presumably of the Tracy Arm and Stikine terranes have also been mapped in parts of British Columbia (Woodsworth and others, 1983 , p. 10). These faults also appear to be intruded by Eocene plutons, but contrary to the relations in the Ketchikan quadrangle, they appear to thrust rocks of the Tracy Arm terrane over those of the Stikine terrane.

\section{STIKINE TERRANE}

Rocks assigned to the Stikine terrane (map sheet, section $A-A^{\prime}$; fig. 3; Berg and others, 1978c) crop out only in a 30 $\mathrm{km}^{2}$ area in the northeast corner of the study area. The rocks consist of recrystallized, presumed upper Paleozoic and Mesozoic sedimentary and andesitic volcanic and volcaniclastic rocks that are cut by Triassic granodiorite that may be cogenetic with some of the volcanic rocks. This assemblage is intruded by Eocene granodiorite and quartz monzonite. The pre-Eocene rocks make up the southwesternmost fringe of a late Paleozoic and younger assemblage of marine and nonmarine volcanic, intrusive, and sedimentary rocks that occur mainly in British Columbia and Yukon Territory (Monger, 1977; Monger and Price, 1979; Monger and Berg, 1985). The Stikine terrane probably originated as a late Paleozoic volcanic arc; its key stratigraphic sequence (in British Columbia) is a thick pile of Lower and Middle Jurassic andesitic volcanic rocks that are unknown in any of the terranes to the west. In the Ketchikan quadrangle the southwest boundary of the Stikine terrane is a postulated thrust zone that has been mostly obliterated by the Eocene plutons.

\section{REFERENCES CITED}

Berg, H.C., 1972, Geologic map of Annette Island, Alaska: U.S. Geological Survey Miscellaneous Geologic Investigations Map I-684, scale 1:63,000, 8 p. 1973, Geology of Gravina Island, Alaska: U.S. Geological Survey Bulletin 1373, 41 P.
1982, The Alaska Mineral Resource Assessment Program: Guide to information about the geology and mineral resources of the Ketchikan and Prince Rupert quadrangles, southeastern Alaska: U.S. Geological Survey Circular $855,24 \mathrm{p}$.

Berg, H.C., and Cruz, E.L., 1982, Map showing locations of fossil collections and related samples in the Ketchikan and Prince Rupert quadrangles, southeastern Alaska: U.S. Geological Survey Open-File Report 82-1088, 1 sheet, scale 1:250,000, $27 \mathrm{p}$.

Berg, H.C., Decker, J.E., and Abramson, B.S., 1981, Metallic mineral deposits of southeastern Alaska: U.S. Geological Survey Open-File Report 81-122, scale 1:1,000,000, $136 \mathrm{p}$.

Berg, H.C., Elliott, R.L., and Koch, R.D., 1978a, Map and tables describing areas of metalliferous mineral resource potential in the Ketchikan and Prince Rupert quadrangles, Alaska: U.S. Geological Survey Open-File Report 78$73 \mathrm{M}$, scale $1: 250,000,48 \mathrm{p}$.

Berg, H.C., Elliott, R.L., Smith, J.G., and Kock, R.D., 1978b, Geologic map of the Ketchikan and Prince Rupert quadrangles, Alaska: U.S. Geological Survey Open-File Report 78-73A, scale 1:250,000.

Berg, H.C., Elliott, R.L., Smith, J.G., Pitman, T.L., and Kimball, A.L., 1977, Mineral resources of the Granite Fiords Wilderness Study Area, Alaska: U.S. Geological Survey Bulletin 1403, $151 \mathrm{p}$.

Berg, H.C., Jones, D.L., and Coney, P.J., 1978c, Map showing pre-Cenozoic tectonostratigraphic terranes of southeastern Alaska and adjacent areas: U.S. Geological Survey Open-File Report 78-1085, 2 sheets, scale 1: $1,000,000$

Berg, H.C., Jones, D.L., and Richter, D.H., 1972, GravinaNutzotin belt-tectonic significance of an Upper Mesozoic sedimentary and volcanic sequence in southern and southeastern Alaska, in Geological Survey Research 1972: U.S. Geological Survey Professional Paper 800-D, p. D1-D24.

Brew, D.A., and Ford, A.B., 1978, Megalineament in southeastern Alaska marks southwest edge of Coast Range batholithic complex: Canadian Journal of Earth Science, v. 15 , no. 11 , p. $1763-1772$.

1981, The Coast plutonic complex sill, southeastern Alaska, in Albert, N.R.D., and Hudson, T.L., eds., The United States Geological Survey in Alaska: accomplishments during 1979; U.S. Geological Survey Circular 823-B, p. B96-B99.

1984, Tectonostratigraphic terranes in the Coast plutonic-metamorphic complex, southeastern Alaska, in Reed, K.L., and Bartsch-Winkler, Susan, eds., The United States Geological Survey in Alaska: accomplishments during 1982: U.S. Geological Survey Circular 939, p. 90-93.

Brew, D.A., and Morrell, R.P., 1979, Intrusive rock belts of southeastern Alaska, in Johnson, K.M., and Williams, J.R., eds., The United States Geological Survey in Alaska: accomplishments during 1978: U.S. Geological Survey Circular 804-B, p. B116-B121.

Brooks, A.H., 1902, Preliminary report on the Ketchikan mining district, Alaska, with an introductory sketch of the geology of southeastern Alaska: U.S. Geological Survey Professional Paper 1, 120 p.

Buddington, A.F., 1929, Geology of Hyder and vicinity, southeastern Alaska, with a reconnaissance of Chickamin River: U.S. Geological Survey Bulletin 807, 124 p.

Buddington, A.F., and Chapin, Theodore, 1929, Geology and mineral deposits of southeastern Alaska: U.S. Geological Survey Bulletin 800, 398 p. 
Chapin, Theodore, 1918, The structure and stratigraphy of Gravina and Revillagigedo Islands, Alaska, in Shorter contributions to general geology 1918: U.S. Geological Survey Professional Paper 120-D, p. 83-100.

Eberlein, G.D., Churkin, Michael Jr., Carter, Claire, Berg, H.C., and Ovenshine, A.T., 1983, Geology of the Craig quadrangle, Alaska: U.S. Geological Survey Open-File Report 83-91, scale 1:250,000, $53 \mathrm{p}$.

Elliott, R.L., Smith, J.G., and Hudson, Travis, 1976, Upper Tertiary high-level plutons of the Smeaton Bay Area, southeastern Alaska: U.S. Geological Survey Open-File Report 76-507, 16 p.

Gehrels, G.E., Brew, D.A., and Saleeby, J.B., 1983a, U-Pb zircon ages of major intrusive suites in the Coast plutonicmetamorphic complex near Juneau, southeastern Alaska [abs.]: Geological Association of Canada Program with Abstracts, v. 8, p. A26.

Gehrels, G.E., and Saleeby, J.B., 1987, Geology of southern Prince of Wales Island, southeastern Alaska: Geological Society of America Bulletin, v. 98, p. 123-137.

Gehrels, G.E., and Saleeby, J.B., and Berg, H.C., 1984, Geologic framework of Paleozoic rocks on southern Annette and Hotspur Islands, southern Alexander terrane, in Coonrad, W.L., and Elliott, R.L., eds., The United States Geological Survey in Alaska: accomplishments during 1981: U.S. Geological Survey Circular 868, p. 113-115. 1983b, Preliminary description of the Late Silurian-Early Devonian Klakas Orogeny in the southern Alexander terrane, southeastern Alaska, in Stephens, C.H., ed., Pre-Jurassic rocks in western North American suspect terranes: Society of Economic Paleontologists and Mineralogists, Pacific Section, Sacramento, Calif., 1983, p. 131-141.

1987, Geology of Annette, Gravina, and Duke Islands, southeastern Alaska: Canadian Journal of Earth Sciences, v. 24, p. 866-881.

Gehrels, G.E., and Saleeby, J.B., Berg, H.C., and Eberlein, G.D., 1983c, Basement continuity and variations in superjacent strata in the southern Alexander terrane, SE Alaska [abs.] 19438: Geological Society of America Abstracts with Programs, v. 15 , no. 5, p. 385.

Grove, E.W., 1971, Geology and mineral deposits of the Stewart area, northwestern British Columbia: British Columbia Department of Mines and Petroleum Resources Bulletin 58, $219 \mathrm{p}$.

Hollister, L.S., 1975, Granulite facies metamorphism in the Coast Range crystalline belt: Canadian Journal of Earth Sciences, v. 12, p. 1953-1955.

Hudson, Travis, Smith, J.G., and Elliott, R.L., 1979, Petrology, composition, and age of intrusive rocks associated with the Quartz Hill molybdenite deposit, southeastern Alaska: Canadian Journal of Earth Science, v. 16, p. 1805-1822.

Hutchison, W.W., 1970, Metamorphic framework and plutonic styles in the Prince Rupert region of the Central Coast Mountains, British Columbia: Canadian Journal of Earth Sciences, v. 7, p. 376-405.

1982, Geology of the Prince Rupert-Skeena map area, British Columbia: Geological Society of Canada Memoir 394, 116 p.

Irvine, T.N., 1974, Petrology of the Duke Island ultramafic complex, southeastern Alaska: Geological Society of America Memoir 138, $240 \mathrm{p}$.

Koch, R.D., and Elliott, R.L., 1984, Late Oligocene gabbro near Ketchikan, southeastern Alaska, in Coonrad, W.L., and Elliott, R.L., eds., The United States Geological Survey in Alaska: accomplishments during 1981: U.S.
Geological Survey Circular 868, p. 126-128.

Koch, R.D., Elliott, R.L., Smith, J.G., and Berg, H.C., 1977, Metamorphosed trondhjemite of the Alexander terrane in Coast Range plutonic complex, in Blean, K.M., ed., The United States Geological Survey in Alaska: accomplishments during 1976: U.S. Geological Survey Circular 751B, p. B72-B74.

MacKevett, E.M., Jr., 1963, Geology and ore deposits of the Bokan Mountain uranium-thorium area, southeastern Alaska: U.S. Geological Survey Bulletin 1154, 125 p.

Monger, J.W.H., 1977, Upper Paleozoic rocks of the western Canadian Cordillera and their bearing on Cordilleran evolution: Canadian Journal of Earth Sciences, v. 14, p. 1832-1859

Monger, J.W.H., and Berg, H.C., 1985, Lithotectonic terrane map of western Canada and southeastern Alaska, in Silberling, N.J., and Jones, D.L., eds., Lithotectonic terrane maps of the North American Cordillera: U.S. Geological Survey Miscellaneous Field Studies Map MF-1874-B, scale 1:250,000.

Monger, J.W.H., and Price, R.A., 1979, Geodynamic evolution of the Canadian Cordillera-progress and problems: Canadian Journal of Earth Sciences, v. 16, p. 770-791.

Roddick, J.A., and Hutchison, W.W., 1974, Setting of the Coast Plutonic Complex, British Columbia: Pacific Geology, v. 8, p. 91-108.

Rubin, C.M., and Saleeby, J.B., 1987, The inner boundary zone of the Alexander terrane, southeastern Alaska-A newly discovered thrust belt [abs.]: Geological Society of America Abstracts with Programs, v. 19, no. 6, p. 445.

Saleeby, J.B., and Gehrels, G.E., 1985, Character of the Alexander-Taku terrane boundary, Cape Fox to Cleveland Peninsula, southeastern Alaska [abs.]: Geological Society of America Abstracts with Programs, v. 17, no. 6 , p. 406.

Saleeby, J.B., Gehrels, G.E., Eberlein, G.D., and Berg, H.C., 1984, Progress in lead/uranium zircon studies of lower Paleozoic rocks of the southern Alexander terrane, in Coonrad, W.L., and Elliott, R.L., eds., The United States Geological Survey in Alaska: accomplishments during 1981: U.S. Geological Survey Circular 868, p. 110-113.

Selverstone, Jane, and Hollister, L.S., 1980, Cordierite-bearing granulites from the Coast Ranges, British Columbia; P-T conditions of metamorphism: Canadian Mineralogist, v. 18 , pt. 1, p. 119-129.

Silberling, N.J., Wardlaw, B.R., and Berg, H.C., 1981, New paleontologic age determinations from the Taku terrane, Ketchikan area, southeastern Alaska, in Coonrad, W.L., ed., The United States Geological Survey in Alaska: accomplishments during 1980: U.S. Geological Survey Circular 844, p. $117-119$.

Smith, J.G., 1973, A Tertiary lamprophyre dike province in southeastern Alaska: Canadian Journal of Earth Sciences, v. 10, p. $408-420$

1977, Geology of the Ketchikan D-1 and Bradfield Canal A-1 quadrangles, southeastern Alaska: U.S. Geological Survey Bulletin 1525, 49 p.

Smith, J.G., and Diggles, M.F., 1981, Potassium-argon determinations in the Ketchikan and Prince Rupert quadrangles, southeastern Alaska: U.S. Geological Survey OpenFile Report 78-73N, 1 sheet, scale 1:250,000, $16 \mathrm{p}$.

Smith, J.G., Stern, T.W., and Arth, J.G., 1979, Isotopic ages indicate multiple episodes of plutonism and metamorphism in the Coast mountains near Ketchikan, Alaska [abs.]: Geological Sociey of America Abstracts with Programs, v. 11 , no. 7, p. 519.

Smith, P.S., 1915, Notes on the geology of Gravina Island, 
Alaska, in Shorter contributions to general geology, 1915: U.S. Geological Survey Professional Paper 95, p. 97-105.

Sutter, J.F., and Crawford, M.L., 1985, Timing of metamorphism and uplift in the vicinity of Prince Rupert, British Columbia and Ketchikan, Alaska [abs.] 70753L Geological Society of America Abstracts with Programs, v. 17, no. 6, p. 411.

Turner, F.J., 1981, Metamorphic petrology: mineralogical, field and tectonic aspects (2d ed.): New York, McGrawHill, $524 \mathrm{p}$.

Turner, F.J., and Verhoogen, John, 1960, Igneous and metamorphic petrology ( $2 \mathrm{~d}$ ed.): New York, McGraw-Hill, $694 \mathrm{p}$.

U.S. Geological Survey, 1977, Aeromagnetic map of Ketchikan, Prince Rupert, and northeastern Craig quadrangles, Alaska: U.S. Geological Survey Open-File Report 77 359,1 sheet, scale 1:250,000.

Williams, Howel, Turner, F.J., and Gilbert, C.M., 1982, Petrography: an introduction to the study of rocks in thin sections (2d ed.): San Francisco, Calif., W.H. Freeman and Co., $626 \mathrm{p}$

Woodsworth, G.J., Crawford, M.L., and Hollister, L.S., 1983, Metamorphism and structure of the Coast Plutonic Complex and adjacent belts, Prince Rupert and Terrace areas, British Columbia: Geological Association of Canada Victoria Section Field Guidebook, v. 2, Field Trip 14, 62 p.

\section{DESCRIPTION OF MAP UNITS}

Qu

Glacial, glacial-marine, alluvial, and talus deposits, undivided (Quaternary) - Unconsolidated deposits of poorly sorted clay, silt, sand, gravel, and boulders locally cover bedrock, sometimes to depths of many meters, throughout the map area. Glacial drift, till, and moraine are partly reworked. A glacial-marine terrace deposit, approximately 3$m$-thick but too small to show on the map occurs at an elevation of about $25 \mathrm{~m}$ about $1 \mathrm{~km}$ northwest of the head of Dall Bay on Gravina Island (Chapin, 1918, p. 99; Berg, 1973, p. 35). It consists of stratified glacial till, gravel, and blue clay and contains Quaternary marine fossils (Berg and Cruz, 1982, No. 37). The unconsolidated deposit mapped at an elevation of about $75 \mathrm{~m}$ west of Blank Inlet on Gravina Island may also be a marine terrace deposit that correlates with the fossiliferous deposit northwest of Dall Bay

Volcanic olivine andesite, trachyandesite, and basalt (Quaternary and Tertiary)-This extrusive unit forms volcanic cones, columnar-jointed lava flows, and rubbly flows containing pumice and scoria; it also includes patches of ash and lapilli a few $\mathrm{cm}$ to a few $m$ thick but too small to show on the map. Postglacial eruption is indicated by volcanic cones at Painted Peak on Revillagigedo Island and elsewhere that still retain their constructional shape with only minor modification by stream erosion, and by unconsolidated pumice, lapilli, and ash deposits that locally cover parts of glaciated ridge tops. Evidence of preglacial eruption includes flows that locally show glacial striae and grooves. K-Ar age determinations (table 1, Nos. 1-3) indicate volcanic activity at about $5 \mathrm{Ma}$ and between about 1.0 $\mathrm{Ma}$ and $0.4 \mathrm{Ma}$

\section{PRINCE OF WALES-GRAVINA-ANNETTE-} MARY-DUKE ISLANDS AREA

Tgb Gabbro (Tertiary)—A small intrusive body of gabbro crops out in tidal exposures on the northeast coast of Gravina Island (Berg, 1973, p. 33-34). The gabbro, which grades into diabase, is a subophitic to ophitic aggregate of plagioclase (An37-58), clinopyroxene, orthopyroxene, olivine, and brown (Z) biotite, and it has subordinate to minor amounts of green biotite, chlorite, magnetite, colorless to pale-green amphibole, apatite, potassium feldspar, and quartz. The olivine crystals are partly replaced by a dark, reddish-brown mineral. This undeformed and unmetamorphosed gabbro is assigned an Oligocene or Miocene age because it is similar to isotopically dated gabbro that crops out about $6 \mathrm{~km}$ to the southeast across Tongass Narrows on Revillagigedo Island (see description of unit $\mathrm{Tgb}$ in the Revillagigedo IslandCleveland Peninsula area)

Kqd Quartz diorite (Cretaceous)-The only mapped outcrop of this unit in this area is on Spire Island off the northeast coast of Annette Island. The unit consists of sheared and hydrothermally altered brownish-gray, medium-grained quartz diorite containing albite and quartz and subordinate muscovite, chlorite, epidote-clinozoisite, calcite, apatite, sphene, and pyrite. It intrudes Jurassic or Cretaceous phyllitic graywacke that is thermally metamorphosed to andalusite hornfels or schist near the contact with the pluton. Muscovite from the pluton yielded a K-Ar age of about $89 \mathrm{Ma}$ (table 1, No. 50). Although the muscovite may have been affected by, or is a product of, hydrothermal alteration, we assign the pluton a Late Cretaceous emplacement age because it intrudes Jurassic or Cretaceous strata

Kpg Plagioclase-porphyritic granodiorite and quartz diorite (Cretaceous)-In this part of the map area, this unit has been recognized in outcrop only on Mary Island. On western Mary Island it consists of a small stock and marginal dikes of massive, medium-grained, plagioclase-porphyritic, biotiteand garnet-bearing, hornblende-epidote quartz diorite. These rocks have sharp, discordant and concordant contacts with the surrounding semischist, and show no evidence of metamorphism or deformation. The quartz diorite typically is characterized by crowded centimetersize subhedral plagioclase phenocrysts separated by a fine- to medium-grained granular aggregate of the other minerals. Magmatic minerals include essential plagioclase and quartz, accessory epidote and green hornblende, and minor amounts of brown biotite, garnet, potassium feldspar, apatite, and opaque minerals. Some plagioclase crystals have multiple delicate oscillatory zones. Epidote forms anhedral to subhedral grains; some are twinned, some are concentrically zoned. Garnet and epidote occur within, but mainly are interstitial to, plagioclase. Minor deuteric alteration consists of chlorite streaks in biotite and scattered small patches of sericite. These rocks, and a small unmapped dike of similar texture and composition that outcrops in the intertidal zone near the southern tip of Mary Island, have the same 
distinctive texture and mineralogy as rocks assigned to unit $\mathrm{Kpg}$ on Revillagigedo Island. On the basis of this comparison, we assign the plagioclaseporphyritic quartz diorite on Mary Island a Late Cretaceous emplacement age

Kum Ultramafic rocks (Cretaceous)-This unit comprises dunite and peridotite, clinopyroxenite and hornblendite. The dunite and peridotite locally are intensely serpentinized, mainly near fault zones.

On Duke Island (Irvine, 1974), a well-exposed concentrically zoned ultramafic intrusive complex has a core of dunite and peridotite and a margin of clinopyroxenite and hornblendite. The olivinebearing units locally show rhythmic layering, slump structure, and other cumulate features. On Duke and Percy Islands the ultramafic rocks intrude Triassic gabbro $(\mathbf{k g})$, and Ordovician or Silurian rocks (SOui). Near some contacts with the ultramafic rocks, the gabbro is metamorphosed to amphibolite and is intruded by dikes of coarse hornblende-plagioclase pegmatite. Elsewhere, ultramafic rocks shown on the map are mainly in fault contact with adjacent rock units. The unit is assigned a Cretaceous age on the basis of $\mathrm{K}-\mathrm{Ar}$ ages ranging from 106 to $134 \mathrm{Ma}$ measured on hornblende from four samples of homblendite and hornblende pegmatite from southern Duke Island (table 1, Nos. 57-61).

The dunite and peridotite in these ultramafic rocks contain small amounts of chromite, asbestos, and platinum-group metals, and the clinopyroxenite locally contains accumulations of titaniferous magnetite (Berg and others, 1981, n. 69, 96). The ultramafic bodies on Duke and Percy Islands have been prospected for iron and chromite

Gravina Island Formation (Jurassic), unnamed (partly correlative) bedded rocks (Cretaceous and Jurassic), and related dioritic intrusive rocks (Cretaceous or Jurassic)-This assemblage consists of flysch and other detrital sedimentary rocks (KJgs), andesitic and basaltic volcanic and volcaniclastic rocks (KJgv), and dioritic intrusive rocks (KJgd) (Berg, 1973, p. 27-33; 1972, p. 1$3)$. The dioritic rocks intrude and locally metamorphose the sedimentary rocks, but locally they are texturally and compositonally gradational with the volcanic rocks. On western Gravina Island the assemblage consists solely of unnamed detrital sedimentary rocks; on eastern Gravina Island it consists of intertonguing sedimentary and volcanic rocks assigned to the Middle or Upper Jurassic Gravina Island Formation (Berg, 1973, p. 28); and on Annette Island it consists of unnamed strata correlative with the Gravina Island Formation and the only mapped occurrence of the diorite. On western Gravina Island, the sedimentary rocks unconformably overlie rocks as old as Ordovician or Silurian; neither the base nor top of the assemblage is exposed elsewhere in the map area. The total thickness of the assemblage has not been measured. Limited data indicate that on western Gravina Island it is at least $200 \mathrm{~m}$ thick (Berg, 1973 , p. 27-28); elsewhere, outcrop widths suggest that it may be as much as $1,000 \mathrm{~m}$ thick (Berg, 1972, p. 2), but its original thickness probably varied from place to place. The maximum outcrop width of $10 \mathrm{~km}$ on Gravina Island probably is due mainly to structural repetition.

On western Gravina Island these rocks are characterized by slaty cleavage and low-grade metamorphism; on eastern Gravina Island and on Annette Island, they are penetratively deformed and regionally metamorphosed to greenschist facies and show increasing metamorphic grade from southwest to northeast.

In the Ketchikan-Prince Rupert area, the assemblage contains fossils of Middle or Late Jurassic age (Berg, 1973, p. 27-30). Outside the area, unnamed rocks that probably correspond with undated upper parts of the assemblage on Annette and Gravina Islands contain wellpreserved ammonites of mid-Cretaceous (Albian) age (Berg and others, 1972, p. D11-D14). On the basis of these regional relations, the assemblage herein is assigned an age range of Middle(?) Jurassic through Early Cretaceous. On northeastern Gravina Island, the assemblage is intruded by a small body of Oligocene or Miocene gabbro.

Locally on northeastern Gravina Island, bedded rocks of the assemblage are hydrothermally altered and cut by sulfide-bearing quartz veins, some of which were successfully worked for gold around the turn of the century (Berg and others, 1981, p. 63-64). Divided into:

KJgd Diorite and quartz diorite (Cretaceous or Jurassic)This elongate stock on northern Annette Island is apparently zoned from a hypidiomorphic granular core to a porphyritic margin. The core typically contains approximately equal parts of relict plagioclase and ferromagnesian crystals, up to about 10 percent quartz, and accessory sphene, apatite, and pyrite. The marginal zone contains relict plagioclase phenocrysts as long as $1-\mathrm{cm}$, both as individual crystals and in clumps, amphibole(?) pseudomorphs of hornblende or pyroxene, and as much as about 10 percent interstitial quartz, pyrite, and undetermined metamorphic minerals. The pluton is massive or locally moderately foliated and is hydrothermally altered. Plagioclase is converted almost entirely to very fine grained albite, epidoteclinozoisite, and sericite, and the ferromagnesian minerals to actinolite, chlorite, and epidote. The pluton intrudes metasedimentary rocks of the Gravina Island Formation with sharp, locally migmatitic contacts. Its contact with the metavolcanic rocks of the Gravina Island Formation, however, apparently is compositionally and texturally gradational, suggesting that the pluton and the metavolcanic rocks are cogenetic (Berg, 1972, p. 1-2). On the basis of these relations, the pluton is assigned an age of Jurassic or Cretaceous

KJgv Andesitic to basaltic volcanic and volcaniclastic rocks and minor sedimentary rocks (Cretaceous and Jurassic) - This unit consists of locally massive but generally foliated and schistose green metavolcanic rocks derived from andesitic and basaltic tuff and agglomerate (Berg, 1972, p. 2; 1973 , p. 31-32). It also contains minor grayishgreen and black phyllite and phyllitic siltstone that gradationally intertongue with the metavolcanic 
rocks. Chemical analyses (Berg and others, 1972, p. D15) show that the most abundant rock type is basaltic andesite. It consists of lithic and crystallithic tuff that contains relict euhedral phenocrysts of plagioclase feldspar and dark ferromagnesian minerals $1 \mathrm{~cm}$ or less in size. The phenocrysts are moderately to strongly saussuritized plagioclase, colorless augite, and pale-green amphibole; the groundmass is a fine-grained microgranular aggregate of relict augite and hornblende and metamorphic actinolite, chlorite, epidote, albite, quartz, muscovite, prehnite, calcite, and leucoxene. Metamorphic textures and minerals (except prehnite) indicate regional greenschist-facies metamorphism that we infer to be Cretaceous in age, on the basis of radiometrically dated Cretaceous metamorphic minerals in the Revillagigedo Island-Cleveland Peninsula area ((see "Metamorphosed sedimentary, volcanic, and intrusive rocks (Mesozoic or Paleozoic)").

On the northeastern shore of Bostwick Inlet (Gravina Island) the unit contains an unmapped intrusive(?) body of massive augite or hornblende porphyry (H.C. Berg and J.B. Saleeby, unpublished data, 1980). This porphyry, which we interpret as a subvolcanic feeder to the extrusive rocks of the Gravina Island Formation, contains locally abundant xenoliths of dark-greenish-black medium- and coarse-grained pyroxene gabbro, whose source may be a buried ultramafic pluton analogous to the ultramafic gabbroic complex on Duke Island

KJgs Sedimentary rocks and minor volcanic rocks (Cretaceous and Jurassic)-On western Gravina Island (Berg, 1973, p. 27-28), this unit consists of basal conglomerate and grit that grade upward and laterally into slaty but otherwise unmetamorphosed, dark-gray, thin-bedded graywacke and minor limestone. Locally the graywacke contains a Buchia fauna indicative of a Late Jurassic age. The conglomerate consists of poorly sorted angular to subrounded clasts, as much as a meter in maximum dimension, derived from stratigraphically underlying units; the matrix is graywacke and grit. On Annette Island and eastern Gravina Island (Berg, 1972, p. 2-3; 1973, p. 3233), the unit consists of regionally metamorphosed greenschist-facies flysch and minor intertonguing andesitic metatuff. The flysch includes phyllitic graywacke, argillite, conglomerate, grit, and minor silty limestone. The conglomerate and grit typically consist of matrix-supported angular to subrounded clasts, as much as a meter long, of green metatuff and dark-gray metaflysch in a metaflysch matrix. Near Rock Point on northeastern Gravina Island, the conglomerate also contains prominent relict roundstones of quartz diorite as much as $25 \mathrm{~cm}$ in diameter (Berg, 1973, p. 32-33). The rocks in this unit on Annette and eastern Gravina Islands differ from those on western Gravina Island by greater intensity of penetrative deformation and regional metamorphism, by intertonguing andesitic and basaltic volcanic and volcaniclastic rocks, and by poorly preserved fossil belemnoids and pectinid clams, possibly of Middle or Late Jurassic age. The intertonguing volcanic rocks are lithically identical to those in the volcanic members of the Gravina

\section{Island Formation}

Gabbro (Triassic) - Much of central and eastern Duke Island is underlain by a large body of pyroxene gabbro that consists of varying proportions of olivine, hypersthene, augite, plagioclase, hornblende, and minor opaque minerals (Irvine, 1974). The gabbro intrudes deformed and metamorphosed Ordovician or Silurian sedimentary and igneous rocks (SOu, SOui), and in turn is intruded by Cretaceous ultramafic rocks (Kum). The gabbro is assigned a Triassic age on the basis of a U-Pb apparent age of $226 \pm 3 \mathrm{Ma}$ (table 1, No. 61a) (Gehrels and others, 1987, p. 878)

Kc

Chapin Peak Formation (Triassic)-This unit, named for its excellent exposures near Chapin Peak on Gravina Island (Berg, 1973, p. 23-26), consists chiefly of marine basaltic volcanic rocks and subordinate intertonguing sedimentary rocks that crop out mainly on western Gravina Island. We provisionally correlate outcrops of basaltic pillow flows and breccia north of Sylburn Harbor on western Annette Island (Berg. 1972, p. 3) with the Chapin Peak Formation on the basis of similar lithology and stratigraphic position. The Chapin Peak Formation is characterized by basaltic pillow flows, calcareous agglomerate and volcanic breccia, and aquagene tuff. The volcanic and volcaniclastic rocks intertongue gradationally with limestone and calcareous clastic sedimentary rocks that are much less abundant and that occur mainly near the base of the formation. Deformation varies from slight pillow flattening and jointing in the relatively massive volcanic rocks to slaty or phyllitic fabric in the fine-grained detrital rocks. The mineralogy and textures suggest that the volcanic rocks have undergone either widespread deuteric alteration or possibly regional metamorphism to the prehnitepumpellyite facies (Berg, 1973, p. 25). Near the fault zone along Bostwick Inlet, the rocks are relatively strongly recrystallized and sheared. Limestone beds and limestone clasts in conglomerate assigned to the Chapin Peak Formation in Bostwick Inlet contain well-preserved Late Triassic (late Norian) fossils (Berg, 1973, p. 24; Berg and Cruz, 1982). The Chapin Peak Formation conformably or disconformably overlies older Upper Triassic sedimentary rocks. On Gravina Island, it is overlain by upper Mesozoic detrital rocks with apparent slight structural, but marked erosional, discordance. The thickness of the formation ranges from about 150 to $500 \mathrm{~m}$. This variation reflects differences in original thickness and in postdepositional erosion. The age of the Chapin Peak Formation is Late Triassic

ksv

Sedimentary and mafic volcanic rocks (Triassic) This unit includes the Upper Triassic Nehenta Formation on Gravina Island (Berg, 1973, p. 1923) and unnamed correlative rocks on Annette Island (Berg, 1972, p. 3). It consists of three intertonguing members: (1) carbonaceous limestone and siltstone that grade into limestone, limestone breccia, and calcareous conglomerate, grit, and sandstone; (2) coarse, trondhjemite-clastrich conglomerate and grit; and (3) basaltic pillow flows, agglomerate, and aquagene tuff. The darker hued rocks contain abundant graphite and locally are strikingly rich in well-crystallized pyrite. The 
carbonaceous limestone and siltstone commonly are intricately folded and complexly lineated. Regional deformation and metamorphism differ from place to place, varying from crude facture cleavage in the coarse conglomerate and grit to phyllitic foliation in the carbonaceous member. On Annette Island, the rocks are regionally metamorphosed to greenschist facies and contain the mineral assemblage sericite, quartz, albite, chlorite, calcite, and epidote-clinozoisite; the intensity of deformation and metamorphism increases from west to east. On Gravina Island, regional deformation and metamorphism generally are less intense than on Annette Island. The carbonaceous beds and the limestone locally contain well-preserved Late Triassic fossils (Berg, 1973, p. 20; Berg and Cruz, 1982). Buddington and Chapin (1929, p. 170) estimated that rocks assigned to this unit on Gravina Island are about $500 \mathrm{~m}$ thick. The unit conformably overlies or is laterally gradational with Upper Triassic limestone and dolomite ( $\mathrm{k} \mid$ ) and felsic volcanic rocks ( $\mathrm{k} v$ ), and it unconformably overlies Devonian and older Paleozoic rocks. It is gradationally and conformably overlain by Upper Triassic mafic volcanic rocks ( $\mathrm{kc}$ ) and unconformably overlain by upper Mesozoic sedimentary rocks (KJgs) The age of this unit is Late Triassic

Limestone and dolomite (Triassic)-This unit consists of dark-bluish-gray, very fine grained recrystallized limestone (metacarbonate) distinguished by solution pits and valleys, caverns, and underground drainage. Most of the limestone is massive and calcitic, but locally it is moderately to thichly bedded and, in a few places, dolomitic. In several places near Crab Bay (Annette Island), this unit contains disseminated galena, sphalerite, and other sulfide minerals (Berg and others, 1981). Dolomitic limestone near Crab and Kwain Bays on eastern Annette Island contains microfossils (conodonts) of Late Triassic age (Berg, 1982, p. 5-7). The unit conformably overlies felsic volcanic rocks; it intertongues laterally with, and is conformably overlain by, carbonaceous limestone and siltstone ( $\mathrm{ksv}$ ). The maximum thickness of the unit is about $70 \mathrm{~m}$. The age of this unit is Late Triassic

Felsic volcanic rocks (Triassic) - This unit includes the Upper Triassic Puppets Formation on Gravina Island (Berg, 1973, p. 10-14) and unnamed correlative rocks on Gravina (Berg, 1973, p. 14 15) and Annette (Berg, 1972, p. 4) Islands. The Puppets Formation is divided into two intertonguing members: massive-appearing, thinly layered recrystallized rhyolite; and recrystallized felsic tuff that varies in composition from latite to rhyolite. The tuff member occurs in discontinuous layers and lenses, generally at or near the base of the formation. At Driest Point on Annette Island, the unit includes rhythmically bedded tuffaceous limestone and calcareous tuff that probably record marine deposition of rhyolitic ash and lapilli. The rhyolite typically consists of thin layers, interpreted as relict flowbands, of aphanite containing minute relict phenocrysts of quartz and feldspar; variants have conspicuous fragmental and spherulitic textures. The tuff varies from massive to schistose fragmental rock that locally contains conspicuous angular clasts of trondhjemite. The degree of deformation and recrystallization varies markedly throughout the unit and seems to depend at least as much on the susceptibility of the original lithologies as on the intensity of regional greenschist-facies metamorphism. Chemical analyses show that the composition of the unit also varies greatly, especially in alkali content (H.C. Berg, unpub. data, 1966-70); the cause of this variation is not known. The unit occurs in a variety of colors, most typically white, pink, or bright red. The reddish hues are caused by abundant disseminated hydrothermal hematite, especially near the base of the unit and in some of the adjacent rocks. Rhyolite near Nehenta Bay (Gravina Island) contains bright-red veinlets of jasper. Locally the hematite is accompanied by pyrite, chalcopyrite, and other sulfide minerals, partly in disseminated grains and partly in fissure veins with barite, calcite, and quartz. Many of these lodes have been prospected for gold, copper, and other metals since about 1900 (Berg and others, 1981, p. 59-70). The unit is assigned a Late Triassic age on the basis of Late Triassic fossils (conodonts) in dolomitic limestone that conformably overlies rhyolite on eastern Annette Island (Berg, 1982, p. 5-7), and on a U-Pb (zircon) apparent age of $225 \pm 3 \mathrm{Ma}$ on a sample of rhyolite from the mouth of Bostwick Inlet on Gravina Island (Gehrels and others, 1987, p. 877). The unit unconformably overlies Devonian or older Paleozoic rocks and is conformably overlain by Upper Triassic carbonate, detrital, and basaltic volcanic rocks. The estimated maximum thickness of the unit is about $350 \mathrm{~m}$

Sedimentary and volcanic rocks (Devonian)-On Annette, Gravina, Harris and Hotspur Islands (Berg, 1972, p. 4-5; 1973, p. 15-16), this unit consists primarily of massive and thinly bedded dolomitic marble and recrystallized limestone and of greenschist facies, locally pyritic, phyllite and semischist derived from graywacke flysch. It also contains feldspathic to arkosic calcareous siltstone and sandstone, conglomerate, calcarenite and limestone breccia, and concretionary dolomite. Where stratigraphic relations can be determined, the unit unconformably overlies Silurian or older Paleozoic rocks and is unconformably overlain by Triassic and younger Mesozoic rocks. In this report the unit is assigned an Early or Middle Devonian age because of the stratigraphic relations and the fossils in limestone and other calcareous rocks (Berg and Cruz, 1982). The structural complexity and poor exposures of this unit prevent measuring its thickness, but it probably is at least several hundred meters thick.

On Prince of Wales Island (Eberlein and others, 1983 , p. 16), rocks here provisionally correlated with unit Dsv (their unit Dvs) consist of flyschlike tuffaceous banded mudstone, graywacke, quartzofeldspathic wacke, and subordinate grit. The flysch section grades upward with increasing carbonate content into (a) tuffaceous marlstone, (b) crudely graded, carbonate-cemented, broken-pillow breccia, and (c) volcanic conglomerate. These beds in turn are gradationally overlain by carbonatecemented lithic lapilli aquagene tuff, subordinate 
basaltic to andesitic pillow flows, volcanic breccia, and conglomerate that contains rounded clasts as much as $1 \mathrm{~m}$ in diameter, of altered leucogabbro, diorite, and mafic dike material probably derived from rocks in unit SOui. Fossils have not been found in this unit on Prince of Wales Island. It is provisionally assigned a Devonian age because of stratigraphic relations and lithologic similarities to faunally dated Devonian rocks elsewhere on Prince of Wales Island (Eberiein and others, 1983, p. 16). Its total exposed thickness is about $1,900 \mathrm{~m}$, but the top of the unit is not exposed

Trondhjemite (Silurian)-This unit consists of the Annette and Central Metlakatla plutons on Annette Island (Berg, 1972, p. 5-7) and correlative unnamed plutonic rocks on Gravina Island (Berg, 1973, p. 8-9). The plutons consist mainly of lightgray trondhjemite composed of sodic plagioclase, quartz, and minor to trace amounts of biotite, hornblende, and potassium feldspar. On Annette Island, the trondhjemite grades northward into a border zone of trondhjemite-quartz diorite distinguished by increasing amounts of biotite and hornblende. On Annette and southern Gravina Islands, the trondhjemite grades locally into granite by increased amounts of potassium feldspar. On southern Gravina Island, the rocks are commonly pink or red because of very finely disseminated hydrothermal hematite (Berg, 1973, p. 9). The margin of the Annette pluton characteristically is a moderately to strongly foliated quartz-plagioclasesericite schist that is difficult to distinguish from the surrounding country rocks. The intermediate and central parts of this pluton commonly are cataclastically deformed, and tightly healed microbreccia and protomylonite are widespread. The unit is assigned a Silurian emplacement age on the basis of preliminary $\mathrm{Pb}-\mathrm{U}$ (zircon) age determinations in the 408-424 Ma range (table 1 , Nos. 82, 84-86, 93)

SOu Extrusive, intrusive, and sedimentary rocks, undivided (Silurian or Ordovician)-This heterogeneous assemblage comprises (a) mafic, intermediate, and subordinate felsic volcanic and volcaniclastic rocks, (b) clastic and carbonate sedimentary rocks, and (c) intermediate and mafic plutonic intrusive rocks. Also, locally divided into: subunit is mapped separately on Prince of Wales Island, on southwestern Annette Island (South Metlakatla pluton of Berg, 1972, p. 6), and on Duke, Mary, and southern Gravina Islands (Berg, 1973, p. 16-19)

East of Clarence Strait, most of the rocks are penetratively deformed to phyllite, semischist, and schist, and are regionally metamorphosed to greenschist and locally amphibolite facies (Berg, 1972, p. 7-8). Premetamorphic extrusive rock types include basaltic tuff, agglomerate, and pillow flows and intermediate and felsic tuff (at least partly spilite and keratophyre); sedimentary rock types include argillite, graywacke-siltstone, limestone, conglomerate, and, in the matrix of some of the pillow flows, red chert; and intrusive rock types include medium- and coarse-grained diorite, hornblende diorite, and quartz diorite Compositional, textural, and structural relations

indicate that at least some of the volcanic and plutonic rocks are cogenetic (Gehrels and others, 1984). A sample of quartz diorite from unit SOu on southern Annette Island east of the mouth of Tamgas Harbor and a sample of quartz diorite from unit SOui on Duke Island have preliminary $\mathrm{Pb}-\mathrm{U}$ (zircon) ages in the 430-450 Ma range (table 1 , Nos. 94, 89). The unit is assigned an Ordovician or Silurian age because it contains isotopically dated Ordovician and Silurian plutonic rocks and cogenetic volcanic rocks; and it is also intruded by isotopically dated Silurian trondhjemite plutons (St). The thickness of the stratified rocks in this unit is unknown.

On the part of Prince of Wales Island bordering the Ketchikan quadrangle, Eberlein and others (1983, p. 12) describe rocks here provisionally correlated with unit SOui (their unit $P_{2}$ ic) as a "Metaigneous complex consisting of masses of diorite-basite migmatite, and irregular intrusive bodies of hornblende and(or) quartz diorite..., leucogabbro, trondhjemite, and minor pyroxenite cut by mafic. . . and felsic dike swarms". Saleeby and others (1984) report preliminary $\mathrm{Pb}-\mathrm{U}$ (zircon) ages for various components of the complex in the 400 - to $500-\mathrm{Ma}$ range. On the same part of Prince of Wales Island, rocks here provisionally correlated with unit $\mathrm{SOu}$ include three units from Eberlein and others (1983, p. 17-20): unit SOs, Ordovician or Silurian marine graywacke, banded mudstone, siltstone, argillite, and associated basaltic flows and fragmental rocks; unit SOv, Ordovician or Silurian marine andesitic to basaltic volcanic and volcaniclastic rocks; and unit $\mathrm{P}_{2} \mathrm{Ew}$, Precambrian or Paleozoic Wales Group consisting of (a) marine andesitic, basaltic, and subordinate felsic flows and fragmental rocks, (b) graywacke, mudstone and shale, and (c) locally interlayered marble. Because the faunal ages of units SOs and SOv of Eberlein and others (1983, p. 18) on Prince of Wales Island are nearly contemporaneous with the preliminary $\mathrm{Pb}-\mathrm{U}$ isotopic ages of igneous rocks in unit SOu east of Clarence Strait (table 1, Nos. 89, 93, and 94), we assume that these three units are correlative. Our provisonal correlation of rocks in the Wales(?) Group in the Ketchikan quadrangle near Port Johnson (Prince of Wales Island) with those in unit SOu is inferred partly from the mapping by Eberlein and others (1983) and partly from more recent geologic mapping and isotopic studies in that area by G.E. Gehrels (oral commun., 1983) Although part of the Wales Group on Prince of Wales Island may be Precambrian in age (Gehrels and Saleeby, 1987, p. 127), the rocks mapped by Eberlein and others (1983, p. 18-19) as the Wales Group near Port Johnson are indistinguishable from those mapped as their unit SOv. On this basis, we infer that most or all of the bedded rocks near Port Johnson probably are Ordovician or Silurian, not Precambrian, in age

On the part of Prince of Wales Island bordering the Prince Rupert quadrangle south of lat $54^{\circ} 55^{\prime}$ N., MacKevett (1963) describes a complex of intrusive igneous rocks that includes pyroxenite, gabbro, quartz diorite, diorite, granodiorite, quartz monzonite, and syenite. These plutons intrude and 
enclose subordinate metamorphosed detrital, calcareous, and volcanic bedded rocks. Mackevett $(1963$, p. 15,40$)$ assigned the intrusive complex a provisional Cretaceous emplacement age and provisionally assigned the bedded rocks a Devonian premetamorphic age. Subsequent $\mathrm{Pb}-\mathrm{U}$ isotopic dating studies and geologic mapping, however, show that the emplacement age of most of the igneous complex is Ordovician or Silurian, as is the premetamorphic age of most of the metamorphosed bedded rocks (Gehrels and Saleeby, 1987). We therefore provisionally correlate the rocks of the intrusive complex with unit SOui and the metamorphosed bedded rocks with unit SOu

\section{REVILLAGIGEDO ISLAND AND \\ CLEVELAND PENINSULA}

Granite and quartz monzonite porphyry (Tertiary) A massive and undeformed quartz- and feldsparporphyritic stock $1 \mathrm{~km}$ in diameter and a swarm of quartz porphyry dikes intrude amphibolite (MzPmv) and hornblende-biotite quartz diorite (Kq) at the mouth of Burroughs Bay. The granite and quartz monzonite porphyry consists of potassium feldspar euhedra as much as $1.5 \mathrm{~cm}$ long and partially resorbed quartz crystals as much as $3 \mathrm{~mm}$ in diameter in a fine-grained groundmass of quartz, plagioclase, potassium feldspar, and minor biotite. Pyrite is disseminated throughout the pluton, and molybdenite occurs locally as thin films coating fracture surfaces. The dikes are mainly aphanite and very fine grained quartz porphyry containing 0.5 - to 3- $\mathrm{mm}$ quartz phenocrysts in an aphanitic groundmass. Some of the dikes contain disseminated pyrite and traces of molybdenite. The pluton is assigned an Oligocene or Miocene emplacement age on the basis of a $\mathrm{K}$-Ar age determination of about $23 \mathrm{Ma}$ (table 1, No. 7) on biotite and chlorite. The sample that was dated probably was collected from an apophysis of this pluton that is too small to show on the geologic map

Gabbro (Tertiary) - A crudely zoned gabbro complex forms an elongate stock near Ketchikan on southwestem Revillagigedo Island (Koch and Elliott, 1984). An olivine-bearing two-pyroxene gabbro makes up the core of the complex; biotitehornblende two-pyroxene gabbro surrounds the core; and a discontinuous zone of quartz-bearing gabbro underlies two areas at the northwest and southeast ends of the complex. Petrographic studies indicate that the internal contacts are probably gradational. The gabbro is not deformed. It intrudes greenschist-facies metavolcanic and metasedimentary rocks and quartz diorite intrusive rocks. Thermal metamorphism of the stratified rocks by the gabbro has produced a zone of hornfels and spotted schist apparently as wide as 3 $\mathrm{km}$ in the adjoining country rocks. This zone is shown by a stippled pattern on the map. The gabbro complex is assigned an Oligocene or Miocene emplacement age on the basis of $\mathrm{K}-\mathrm{Ar}$ age determinations on biotite and homblende of about 23-25 Ma (table 1, No. 5)

Klg Leucocratic granodiorite, quartz monzonite, and aplite (Cretaceous) - This unit comprises three mapped plutons on east-central Revillagigedo Island. The largest body, east of Manzanita Lake, is an elongate ( $18 \mathrm{~km}$ by $7 \mathrm{~km}$ ) pluton of leucocratic granodiorite that may actually comprise several different plutons too small to show or indistinguishable at reconnaissance mapping scale. The pluton is dominantly medium- to fine-grained hypidiomorphic granular granodiorite. Locally it is foliated, and has thin muscovite or biotite partings evenly spaced 2-10 mm apart; in places near east Behm Canal it is gneissic. Color index ranges from 0 to 15 , but it is mainly between 0 and 2 . The abundance of leucocratic aplite $(\mathrm{CI}=$ approximately 0 ) varies from sparse patches to more than 70 percent of some outcrops. Near its margins the pluton contains structurally discordant xenoliths of amphibolite as long as several meters. Most outcrops are cut by albite(?)-quartz pegmatite dikes that locally contain very coarse muscovite and (or) biotite. In some places, these dikes constitute most of an outcrop. North of Manzanita Creek, outcrops composed almost entirely of this pegmatite were mapped with this pluton.

Near Mount Reid this unit forms two stocks of foliated leucocratic biotite quartz monzonite containing 1-2 percent dark-red garnet. Biotite, the only mafic mineral, makes up as much as 10 percent of the rock, and forms thin films, layers, streaks, and, locally, clots as large as $2 \mathrm{~cm}$ in diameter. The plutonic and metamorphic rocks mapped between Manzanita Lake and Mount Reid contain pegmatite and aplite dikes and sills too small to show on the map. The dikes and sills range from a few centimeters to more than $100 \mathrm{~m}$ thick, and appear to be spatially and genetically related to the stocks. The dikes occur in swarms that locally dominate outcrops within this area. Subhorizontal sheets of aplite cap some ridge tops and form prominent bands across nearly vertical cliff walls. The aplite varies from massive to moderately foliated and is characterized by sugary texture, low color index ( 0 to 5 percent biotite), and a few small pink garnet euhedra. Locally it contains quartz and feldspar phenocrysts. The aplite is cut by abundant albite(?)-quartz pegmatite dikes that locally contain coarse biotite and (or) muscovite, and a trace of garnet. Foliation in the rocks assigned to this map unit appears to generally increase northward, as does the regional metamorphic grade of the enclosing sedimentary and volcanic country rocks. In many places, however, intrusive contacts of apophyses of this unit are less penetratively deformed than the enclosing metamorphic country rocks, suggesting that at least some of the unit was emplaced after, or during the waning stages of, the regional metamorphism of the country rocks. Rocks mapped with this unit have not been dated by isotopic methods. We assign the unit a Cretaceous emplacement age because its structural characteristics and contact relations are consistent with emplacement during and after the waning stages of the regional metamorphism that we believe is Cretaceous in age ((see "Metamorphosed sedimentary, volcanic, and intrusive rocks (Mesozoic or Paleozoic)") 

form stocks $5 \mathrm{~km}$ or less in outcrop diameter, and dikes and sills too small to show on the map. Primary igneous textures predominate. The rocks are locally foliated but rarely show evidence of deformation or metamorphism except in some of the thin, unmapped sills. Typical samples contain conspicuous white plagioclase phenocrysts as large as $3 \mathrm{~cm}$ that make up $50-60$ percent of the rock. The groundmass consists of fine-grained quartz (820 percent), potassium feldspar $(<1-10$ percent $)$, biotite (5-25 percent) and hornblende (0-15 percent). Primary (magmatic) garnet and epidote occur as anhedral to euhedral crystals as large as 3 $\mathrm{mm}$. Epidote occurs within, but mostly interstitial to, plagioclase. It commonly forms 2-5 percent, but locally forms over 10 percent of the rock. Composition of the epidote varies from sample to sample, but at least some is the iron-free variety (clinozoisite). Some of the garnet occurs in the cores of plagioclase phenocrysts, and some as discrete crystals, but it rarely makes up more than 1-2 percent of any sample. Secondary minerals locally include clinozoisite-epidote, white mica, and chlorite. Within the outcrop areas of this map unit are a few small, otherwise unassigned intrusive rocks that include aplite, pegmatite, and diorite. Some of the mapped plutons appear to be crudely zoned: cores are massive porphyritic garnet- and epidote-bearing quartz diorite, and margins are massive foliated equigranular granodionite. Primary (magmatic) flow foliation, when present, is more conspicuous near the margins, where it commonly is parallel to the metamorphic foliation of the intruded country rocks. Field relations indicate that most of the unmapped dikes and sills and some of the smaller mapped plutons are nearly parallel to the compositional layering of the metamorphic country rocks, whereas the contacts of most of the larger plutons clearly intersect the metamorphic layering. Plutons that have crosscutting contacts are accompanied in some places by narrow aureoles that show thermal metamorphism to hornblendehornfels facies, that overprints the metamorphic foliation of the country rocks. These petrographic, structural, and metamorphic relations indicate that most of the plutons assigned to this unit were emplaced after the regional metamorphism and deformation of the country rocks, but that at least some of the mapped plutons and unmapped dikes and sills may have been emplaced during the waning stages of metamorphism and deformation. The unit is assigned an emplacement age of Late Cretaceous on the basis of radiometric age determinations of 82-97 Ma (table 1, Nos. 51, 52) batholith of generally massive hornblende quartz diorite and granodiorite crops out on northern Revillagigedo Island and adjacent Cleveland Peninsula. In places, the pluton is weakly foliated or contains abundant ellipsoidal dark inclusions that commonly are parallel to aligned hornblende crystals and impart a pronounced lineation. Near east Behm Canal, the pluton is locally gneissic. Locally prominent features include zones of angular agmatite and dikes and veins of light-gray-

$\mathrm{Kg}$

Kum weathering quartz-feldspar (-biotite-garnet) pegmatite. Garnet partially replaced by chlorite occurs in many outcrops, and all samples of the pluton examined in thin section contain magmatic epidote. The pluton is assigned a Late Cretaceous emplacement age on the basis of $\mathrm{Pb}-\mathrm{U}$ (zircon) age determinations of approximately $90 \mathrm{Ma}$ for samples collected from northern Revillagigedo Island and Yes Bay (table 1, Nos. 42, 46)

Epidote-biotite-hornblende granodiorite (Cretaceous)-This pluton, which also includes minor amounts of quartz diorite, is characterized by nearly ubiquitous apple-green magmatic epidote. Textures and compositions vary greatly. The pluton is relatively massive in parts of its interior, but along some margins it grades into fine-grained quartzofeldspathic schist (blastomylonite and mylonite schist) containing only barely recognizable relict porphyroclasts of granitic rock. The pluton is most schistose along Revillagigedo Channel, but schistose zones occur sporadically throughout the unit. The pluton is assigned a Late Cretaceous age on the basis of a hornblende plateau ${ }^{40} \mathrm{Ar} /{ }^{39} \mathrm{Ar}$ cooling age determination of 96-97 Ma (Sutter and Crawford, 1985, p. 411) (table 1, No. 55)

Ultramafic rocks (Cretaceous)-This unit consists chiefly of rusty-weathering, massive-appearing, dark-greenish-black biotite- or clinopyroxenebearing hornblendite and hornblende clinopyroxenite. Thin-section studies show coarse xenomorphic aggregates of hornblende and clinopyroxene and accessory sphene, apatite, and opaque minerals; some samples also contain accessory biotite. The clinopyroxene commonly is partly altered to pale-green hornblende. Hydrothermal or metamorphic minerals include biotite, chlorite or antigorite, talc(?), actinolite(?), epidote, and calcite. At Alava Bay (southern Revillagigedo Island), biotite homblendite intrudes metamorphosed bedded rocks and Early Cretaceous granitic rocks $(\mathrm{Kg})$, and it is intruded by undated granitic dikes too small to show on the map. The contacts of ultramafic rocks mapped elsewhere on Revillagigedo Island were not observed during this investigation. Aeromagnetic characteristics (U.S. Geological Survey, 1977) suggest that the body near Clover Passage (southwestern Revillagigedo Island) may be intrusive and that bodies east and west of Thorne Arm may be thin, relatively flat-lying thrust sheets or slabs (Andrew Griscom, oral commun., 1977). The hornblendite at Alava Bay is assigned a late Early Cretaceous emplacement age because a K-Ar age determination on hornblende gave an age of about $99 \mathrm{Ma}$ (table 1, No. 56). Other ultramafic bodies mapped on Revillagigedo Island have not been dated by isotopic methods. In this report they are provisionally correlated with the body at Alava Bay on the basis of similarities in mineralogy, texture, and geologic setting

Setamorphosed sedimentary rocks (Triassic)-This complexly folded and regionally metamorphosed greenschist-facies unit, mapped only along the east shore of George Inlet on southwestern Revillagigedo Island, consists chiefly of thinly interbedded (average thickness less than $25 \mathrm{~cm}$ ) pyrite-bearing carbonaceous (graphitic) slate, 
phyllite, and fine-grained recrystallized limestone that locally contains slightly to moderately flattened spheroidal carbonaceous and siliceous concretions as much as $6 \mathrm{~cm}$ in diameter. Three less abundant but locally conspicuous lithologies are also mapped with this unit: silvery-gray pyritic phyllite; rustyweathering phyllite or schist (possibly derived from felsic or intermediate tuff) containing pyrite, quartz, muscovite, mariposite(?), and calcite or dolomite; and outcrops of massive to laminated gray marble similar to that in the Permian marble unit $(\mathrm{Pm})$. About $4.5 \mathrm{~km}$ south of Coon Cove, concretions from carbonaceous slate and limestone contain fossil bivalves and ammonites of latest Middle Triassic (late Ladinian) age (Silberling and others, 1981, p. 118-119). Other fossil remains include locally abundant crinoid remnants (disks) in the gray marble

Metamorphosed sedimentary, volcanic, and intrusive rocks (Mesozoic or Paleozoic)-Most of Revillagigedo Island and Cleveland Peninsula are underlain by a complexly deformed and metamorphosed assemblage of sedimentary rocks, intermediate or mafic volcanic and volcaniclastic rocks, and relatively sparse intermediate or mafic plutonic rocks. In most places, the rocks show evidence of at least two stages of metamorphism: an early regional metamorphism that increases in intensity northward and eastward from greenschist to amphibolite facies; and a later metamorphism manifested by porphyroblastic minerals that replace the older metamorphic minerals or that randomly overprint the earlier foliation or schistosity. Some of this later metamorphism occurs in thermal aureoles surrounding the Cenozoic and some of the Cretaceous plutons. Except for the hornfels zone in the metamorphosed sedimentary rocks adjacent to the Tertiary gabbro body ( $\mathrm{Tgb}$ ) near Ketchikan, these metamorphic aureoles are too small to show on the map. Depending on the original composition of the country rocks, contact metamorphic minerals in thermal aureoles include biotite, andalusite, muscovite, garnet, staurolite, amphibole, cordierite, sillimanite, wollastonite, and diopside; these minerals suggest that the intensity of thermal metamorphism varies from albiteepidote hornfels to pyroxene hornfels facies (Turner, 1981).

Other evidence of complex metamorphism includes the widespread development of feathery or bowtie-like porphyroblastic aggregates of actinolite, commonly in a matrix of muscovite and garnet, that postdates an older foliation or schistosity. Herein informally called "feather schist" or "garbenschiefer," (Turner and Verhoogen, 1960 , p. 649), this feature is widespread on southern and southwestern Revillagigedo Island, where in places it is manifested by sheaves of actinolite crystals as long as $2 \mathrm{~m}$, almandine(?) garnet euhedra as much as $2 \mathrm{~cm}$ in diameter, and coarsely crystalline muscovite. The age and origin of this feather schist is unknown. Because we did not observe the schist in the regionally metamorphosed amphibolite-facies sedimentary and volcanic rocks on Cleveland Peninsula and on northern and eastern Revillagigedo Island, we think that the feather schist (a) was destroyed by the amphibolite-facies metamorphism there or (b) is gradational with the amphibolite facies metamorphic rocks. Possibly the feather schist on southwestern Revillagigedo Island could be compositionally controlled by rocks that do not occur on northern and eastern Revillagigedo Island or it may be the result of some process that affected the rocks on southwestern but not northem or eastern Revillagigedo Island.

$\mathrm{K}$-Ar age determinations have been made on several minerals from the metasedimentary and metavolcanic rocks in this assemblage on Revillagigedo Island (table 1, Nos. 62-69), but no systematic attempt has been made to distinguish or date individual metamorphic events. Maximum apparent ages of minerals in the regionally metamorphosed greenschist facies strata on central and southern Revillagigedo Island are about $85 \mathrm{Ma}$ for biotite and $87 \mathrm{Ma}$ for hornblende. Maximum apparent ages in the regionally metamorphosed amphibolite-facies strata on northern Revillagigedo Island are about $96 \mathrm{Ma}$ for biotite, $83 \mathrm{Ma}$ for hornblende, and $84 \mathrm{Ma}$ for muscovite; maximum age of these rocks on the eastern part of the island is about $51 \mathrm{Ma}$ for biotite and $74 \mathrm{Ma}$ for homblende. Maximum apparent ages in feather schist from the central part of the island are about $86 \mathrm{Ma}$ for biotite and $93 \mathrm{Ma}$ for hornblende. The age determinations show an increase in discordance and decrease in maximum apparent ages northward and eastward on Revillagigedo Island. Because virtually all ages, however, fall in the mid- to Late Cretaceous age range, we suggest that much if not most of this regional metamorphism took place in mid- to Late Cretaceous time. The discordance and decrease in maximum apparent ages northward and eastward on Revillagigedo Island is a manifestation there of a widespread regional disturbance to K-Ar systems during Tertiary time (Smith and Diggles, 1981, p. 3 ). The cause of this disturbance is unknown, but it has been attributed either to progressive regional uplift and cooling (Hutchison, 1970) or to widespread heating of enigmatic origin (Smith and others, 1979).

Fossils have not been identified in the metasedimentary and metavolcanic rocks mapped with this assemblage. In this report, the strata are assigned a premetamorphic age of late Paleozoic or Mesozoic for four reasons. (1) Some of the metaflysch and ferromagnesian- porphyritic metavolcanic rocks that crop out on Cleveland Peninsula and southwestern Revillagigedo Island are similar in lithology, texture, and geologic setting to faunally dated Jurassic and Cretaceous flysch (KJgs) and volcanic rocks (KJgv) that crop out on Gravina and Annette Islands. The largest outcrop areas of the metaflysch and metavolcanic rocks are on Cleveland Peninsula southwest of Helm Bay and on Revillagigedo Island from Mountain Point to Clover Passage. (2) On the west shore of upper Thorne Arm, the metavolcanic rocks appear to be interlayered with Permian marble (Pm). (3) Field observations suggest that the metaconglomerate mapped from Carroll Inlet to Thorne Arm is at least structurally conformable and possibly is depositionally gradational with the Permian marble 
unit and intertonguing basaltic metavolcanic rocks. (4) Dark-gray pyrite-rich graphitic marble interbedded with metapelite near the abandoned cannery on the west shore of George Inlet is similar in lithology and texture to some of the Middle Triassic marble and recrystallized carbonaceous limestone (Ks) that crops out south of Coon Cove on the opposite shore on the inlet. A sample of the recrystallized graphitic limestone was tested for microfossils (conodonts) but was barren (Berg and Cruz, 1982). The metamorphosed intrusive rocks mapped with the assemblage are assigned a late Paleozoic and Mesozoic emplacement age because their compositions, textures, and field relations suggest that they may be cogenetic with some of the metavolcanic rocks.

We have subdivided the assemblage into five map units on the basis of their premetamorphic lithology: metamorphosed sedimentary rocks and minor intermediate and mafic metavolcanic and volcaniclastic rocks ( $\mathrm{Mz} \mathrm{P}_{2 \mathrm{~ms}}$ ); metamorphosed intermediate and mafic volcanic and volcaniclastic rocks and minor sedimentary rocks ( $\left.\mathrm{MzP}_{2} \mathrm{mv}\right)$; polymictic metaconglomerate ( $\mathrm{MzZ} 2 \mathrm{mc})$; metamorphosed intrusive rocks ( $\left.M z P_{2} m i\right)$; and undivided metamorphosed sedimentary, volcanic, and intrusive rocks $\left(\mathrm{M}_{2} \mathrm{P}_{2} \mathrm{u}\right)$ :

MzPzs Metasedimentary rocks-This unit was derived from pelitic and semipelitic flysch gradationally interbedded with relatively minor amounts of andesitic or basaltic volcanic or volcaniclastic rocks. On southwestern Revillagigedo Island and on Cleveland Peninsula south of Spacious Bay, the prevailing lithology is dark-gray and silvery-gray phyllite and fine-grained semischist; there are subordinate layers of green phyllite and semischist. The gray phyllite and semischist contain quartz, feldspar, and varying amounts of biotite, garnet, muscovite, pyrite, graphite, hornblende or actinolite, calcite, and chlorite. The micaceous minerals commonly have two habits: as platy crystals aligned parallel to schistosity, and as idioblasts (or chlorite pseudomorphs) as much as a $\mathrm{cm}$ long that intersect the foliation at all angles. Thin sections of the green layers show fine-grained schist containing hornblende, subordinate quartz or plagioclase, and minor to trace amounts of biotite, pyrite, garnet, and epidote-clinozoisite. In some samples, hornblende metacrysts as long as $1 \mathrm{~cm}$ crosscut the foliation. The unit also contains minor feather schist, fine-grained quartz-muscovite schist possibly derived from quartzite or chert, and phyllitic polymictic grit and conglomerate that in places contain relict clasts of leucocratic plutonic rocks. Locally conspicuous layers of rustyweathering schist as thick as 2-3 m contain quartz, plagioclase, calcite, biotite, muscovite, garnet, epidote-clinozoisite, chlorite, and pyrite. These layers may be relict beds of calcareous felsic or intermediate metatuff or other volcanogenic material. Locally the unit contains auriferous quartz veins and disseminated and massive sulfide deposits that have been prospected for gold, silver, copper, lead, and zinc (Berg and others, 1981, p. 59-70).

On northern and eastern Revillagigedo Island and on Cleveland Peninsula from Spacious Bay to the north, the unit is mainly rusty-weathering crystalline gneiss and schist consisting of alternate layers $1 \mathrm{~cm}$ to $2 \mathrm{~m}$ thick of pelitic and quartzofeldspathic rocks. It also contains subordinate dark-gray gneiss, dark-green hornblende-rich schist and gneiss, and minor marble. Quartz veins and lenses as much as a meter thick commonly parallel the gneissic layering. Thin-sections of the pelitic gneiss show strongly schistose, granoblastic, and idioblastic textures. Typical specimens contain (a) quartz, plagioclase, biotite, garnet, and muscovite, (b) accessory clinopyroxene, calcite, sphene, apatite, and pyrite, and (c) retrograde chlorite, epidote, and sericite. Sillimanite occurs mainly in a narrow zone adjacent to the quartz diorite batholith $(\mathrm{Kq})$ on northern Revillagigedo Island and neighboring Cleveland Peninsula; kyanite and staurolite occur in a zone at least $2 \mathrm{~km}$ wide beyond the sillimanite zone. The quartzofeldspathic component of the gneiss is distinguished from the pelitic component by a stronger granoblastic fabric and by more quartz and plagioclase. The dark-gray gneiss is similar in mineralogy and fabric to the rusty-weathering pelitic gneiss but is distinguished from it by greater abundance of hornblende. The hornblende-rich gneiss is distinguished by contrasting alternating layers of dark-greenish-black hornblende-biotitequartz-plagioclase schist and light-gray quartzplagioclase schist.

Throughout the areal extent of this unit, the metamorphic minerals and textures indicate regional metamorphism that grades northward and eastward from greenschist facies to amphibolite facies. On southwestern Revillagigedo Island and neighboring Cleveland Peninsula the regional metamorphic fabric is locally overprinted by lowpressure metamorphism to pyroxene hornfels facies that occurs in intrusive aureoles. The largest such aureole surrounds the Tertiary gabbro pluton near Ketchikan and is indicated by a stipple pattern on the map. Composition of the aureole changes gradationally from a zone of sillimanite-, cordierite-, and staurolite-bearing hornfels near the pluton to a periphery that is indistinguishable from the regionally metamorphosed greenschist-facies metasedimentary rocks.

The unit is intruded by diverse mapped plutons and by numerous unmapped dikes and sills of massive, moderately foliated, or (rarely) schistose, locally garnet-bearing and feldspar-porphyritic aphanite, aplite, pegmatite, and fine-grained granodiorite.

The unit grades into metamorphosed volcanic rocks (MzPzmv) on southwestern Revillagigedo Island and neighboring Cleveland Peninsula where it has more green phyllite and semischist and on northern and eastern Revillagigedo Island and neighboring Cleveland Peninsula where it has more homblende-rich schist and gneiss

MzPzmv

Metavolcanic rocks-This unit was derived primarily from submarine andesitic or basaltic lava flows, tuff, and agglomerate and from subordinate gradationally intertonguing pelitic and semipelitic flysch. On Cleveland Peninsulsa southwest of Helm 
Bay and on southwestern Revillagigedo Island from Mountain Point to Clover Passage, the metavolcanic rocks are distinguished by conspicuous relict euhedral ferromagnesian phenocrysts (now homblende or actinolite pseudomorphs of clinopyroxene) as long as $2 \mathrm{~cm}$. Outcrops of this porphyry range from thick, massive-appearing layers or lenses of coarse, blocky, dark-green breccia to light-green semischist and thinly laminated and lineated very fissile phyllite. Minerals identified in thin section indicate regional metamorphism to greenschist facies and typically include albite, quartz, chlorite, epidote, actinolite, calcite, pyrite, and sphene.

Elsewhere on southwestern Revillagigedo Island and on Cleveland Peninsula northeast of Helm Bay, the unit consists chiefly of dark-green, silverygreen, and greenish-gray phyllite, semischist, and schist, minor marble, and some gray phyllite and semischist. In places along the shorelines of Carroll Inlet, Thorne Arm, and east Behm Canal, it displays well-preserved pillow structures and related volcanic-fragmental textures. Thin sections show that the prevailing lithology is fine-grained schist containing varying amounts of blue-green hornblende and actinolite, albite, chlorite, quartz, plagioclase, epidote, and pyrite. The amphibole crystals occur both parallel to the schistosity and as poikiloblastic euhedra as long as $1 \mathrm{~cm}$ that intersect the foliation at all angles. The gray phyllite is lithically identical to the prevailing rock type described in unit MzPzms. The unit also contains minor feather schist and fine-grained quartzmuscovite schist, possibly derived from quartzite or chert. Near the head of Thorne Arm, quartz veins and other lodes in the unit have been successfully worked for gold and prospected for copper, lead, zinc, and precious metals (Berg and others, 1981, p. 59-70). On northern and eastern Revillagigedo Island, the unit is mainly dark green and dark gray amphibolitic and subordinate quartzofeldspathic schist and gneiss. It also contains sparse layers of marble and rusty-weathering pelitic gneiss. Petrographic studies of the amphibolite show strongly schistose and idioblastic textures. Typical specimens contain hornblende, biotite, quartz, and plagioclase and have accessory sphene, apatite, potassium feldspar, and pyrite, and retrograde chlorite and epidote. The quartzofeldspathic rocks are distinguished by granoblstic fabric and by more quartz and plagioclase. The mineralogy and fabric of this pelitic gneiss are identical to those of the pelitic gneiss in unit $\mathrm{M}_{2} \mathrm{R} 2 \mathrm{~ms}$. The amphibolite is characterized by ubiquitous veins and dikes as much as several meters thick, of leucocratic quartzplagioclase-biotite-gamet pegmatite and aplite that contrast strikingly with the dark hues of the enclosing amphibolite. Locally, the leucocratic rocks form spectacular swarms of randomly oriented dikes that make up as much as half of the outcrop.

The metamorphic minerals and textures in this unit throughout its areal extent indicate regional metamorphism that grades northeastward from greenschist facies to amphibolite facies. On southwestem Revillagigedo Island and neighboring Cleveland Peninsula, the regional metamorphic fabric is locally overprinted in contact aureoles by low-pressure metamorphism to the homblendehornfels facies. The only such aureole shown on the map surrounds the Tertiary gabbro near Ketchikan and is indicated by a stipple pattern. Contact minerals identified in this aureole are listed under unit $\mathrm{MzP}_{2} \mathrm{~ms}$.

The unit is intruded by diverse mapped plutons and by numerous unmapped dikes and sills of massive to (rarely) schistose, locally garnet-bearing and feldspar-porphyritic aphanite, aplite, and pegmatite and fine-grained granodiorite.

The unit grades lithically into metamorphosed sedimentary rocks (MzPzms) on southwestern Revillagigedo Island and neighboring Cleveland Peninsula where it has more gray phyllite and semischist and on northern and eastern Revillagigedo Island where it has more pelitic schist and gneiss

MzRmc Polymictic metaconglomerate-The mapped areas of this unit are on Revillagigedo Island between Carroll Inlet and Thorne Arm, on and near Back Island in Clover Passage, and near Lake Harriet Hunt; and on Cleveland Peninsula on the northeast shore and adjacent islets of Helm Bay. Between Carroll Inlet and Thorne Arm, the unit is characterized by prominent spheroidal to ellipsoidal relict clasts of fine- to coarse-grained leucocratic plutonic rocks as much as $20 \mathrm{~cm}$ in diameter. Other relict clasts are more strongly deformed and include quartzite as well as phyllite and semischist derived from fine-grained sedimentary and possibly volcanic rocks. Thin sections show that the matrix is fine-grained schist containing quartz, plagioclase, biotite, epidote-clinozoisite, garnet, calcite, muscovite, and pyrite. Some of the biotite and garnet crystals are partly altered to chlorite. Some chlorite pseudomorphs (of biotite?) are perpendicular to foliation. Thin sections of representative plutonic clasts show fine- to medium-grained (relict) xenomorphic, granoblastic, and interlocking mosaics of quartz and plagioclase and minor biotite, muscovite, epidote-clinozoisite, calcite, chlorite, and garnet. Chemical analyses (Z.A. Hamlin, unpub. data, 1977), combined with the petrographic data, suggest that these clasts are probably metamorphosed trondhjemite. The metaconglomerate occurs in layers as thick as $2 \mathrm{~m}$. It also contains thin layers of gray phyllite and semischist containing relatively sparse pebbles of leucocratic plutonic rocks. The unit grades structurally upward into gray phyllite that contains diminishing numbers of relict clasts and it grades downward into intercalated green and gray phyllite and semischist. At Gnat Cove on Carroll Inlet, the structurally lowermost part of the unit contains a few lenses of brown-weathering marble.

At Back Island, metaconglomerate is interbedded with flysch. It contains prominent relict rounded clasts of recrystallized leucocratic plutonic rocks as much as $25 \mathrm{~cm}$ in diameter, as well as smaller, less prominent and more deformed relict clasts of white marble, dark-hued flysch, and quartzite(?). The matrix is pelitic phyllite and semischist similar to that in the enclosing metasedimentary rocks.

In an outcrop of polymictic metaconglomerate about $3 \mathrm{~km}$ southwest of Lake Harriet Hunt, about 
10 percent of the rock consists of relict clasts in a matrix of pelitic schist containing quartz, plagioclase, muscovite, biotite, garnet(?), and chlorite(?). The relict clasts average about $5 \mathrm{~cm}$ in maximum dimension. The most prominent relict clasts are slightly flattened roundstones as much as $30 \mathrm{~cm}$ in diameter of leucocratic plutonic rock consisting of quartz, feldspar, and a small percentage of dark, mainly micaceous minerals. Less prominent are ellipsoidal and lensoidal relict clasts, apparently originally of fine-grained felsic igneous or pelitic(?) sedimentary rocks. The most attenuated of these clasts are elongate lenses 15 $\mathrm{cm}$ long and $1 \mathrm{~cm}$ thick parallel to the schistosity.

At Helm Bay, metamorphosed conglomerate and grit layers as thick as $2 \mathrm{~m}$ are intercalated with flysch. The metaconglomerate is very fissile and contains markedly flattened (paper-thin) to nearly perfectly spheroidal relict clasts $5-6 \mathrm{~cm}$ in maximum dimension. Clast compositions include argillite or metapelite (most flattened), indeterminate fine-grained rocks, and medium- and fine-grained silicic igneous rocks (least deformed) The matrix of the metaconglomerate is metapelite.

Unmapped polymictic roundstone metaconglomerate that contains prominent relict clasts of leucocratic igneous rocks occurs in a small xenolith or roof pendant, accompanied by marble, in Cretaceous granodiorite $(\mathrm{Kg})$ on the east shore of Thorne Arm about $5.8 \mathrm{~km}$ from Cone Point. Metaconglomerate is also associated with apparent structurally intercalated marble (Pm), metasedimentary ( $\left.\mathrm{M}_{2} \mathrm{P}_{2} \mathrm{~ms}\right)$, and metavolcanic (MzPzmv) rocks near Ape Point on the southeast coast of Revillagigedo Island, where the metaconglomerate also contains relict clasts of marble (M.L. Crawford, oral commun., 1982)

Metamorphosed intrusive rocks-Mainly regionally metamorphosed or otherwise recrystallized or altered diorite, quartz diorite, and gabbro. The body at Smuggler's Cove (southeastern Cleveland Peninsula) consists of dark-greenish-gray hypidiomorphic-granular diorite and ferromagnesian-porphyritic diorite containing magmatic plagioclase, magmatic or secondary hornblende(?), and secondary epidote, chlorite, and calcite. Rocks of the porphyritic phase closely resemble some of the enclosing metavolcanic rocks (MzPmv). West of Port Stewart (Cleveland Peninsula) a body of massive to foliated hornblende-biotite dionite, quartz diorite, and gabbro coincides with a positive aeromagnetic anomaly (U.S. Geological Survey, 1977). This body may be a structurally detached fragment of a Cretaceous zoned ultramafic intrusive complex near Union Bay, about $6 \mathrm{~km}$ beyond the west boundary of Ketchikan quadrangle (Eberlein and others, 1983, p. 4-5). North of Coon Cove (Revillagigedo Island, George Inlet), a pluton mapped with this unit consists of fine-grained diorite(?) that contains magmatic(?) quartz, plagioclase, and biotite and has metamorphic actinolite, chlorite, and epidote. Southwest of Lake Grace, another pluton consists mainly of massiveappearing dark-greenish-gray coarse schist containing equant clumps of hornblende as much as $2 \mathrm{~cm}$ in diameter; the clumps are enclosed by hornblende-biotite-plagioclase-quartz schist. The bodies south of Neets Bay and north of Emma Lake consist mainly of massive amphibolite containing hornblende, plagioclase, and variable amounts of biotite, garnet, pyrite, pyroxene, and quartz. Outcrops of relatively unmetamorphosed hornblende-plagioclase diorite and gabbro locally occur with the amphibolite. Field relations suggest that the plutonic rocks grade into the amphibolite as the metamorphism increases. The intrusive body near the mouth of Carroll Creek consists of relatively massive metadiorite(?) and fine-grained hornblende-plagioclase schist probably derived from it

MzPzU Metamorphosed sedimentary, volcanic, and intrusive rocks, undivided-This unit consists chiefly of phyllite, semischist, and schist derived from diverse sedimentary, volcanic, and intrusive rocks. Because the unit is so heterogeneous, the principal lithologies are listed, in approximate order of decreasing abundance, for each map area.

Point Alava area: muscovite-calcite (or dolomite) schist; phyllitic siltstone, mudstone, and graywacke; massive blastomylonitic granodiorite; phyllitic to schistose, intermediate or mafic volcanic or volcaniclastic rocks; feather schist; marble; and clinopyroxenite.

Coastal area from southeast of Carroll Point to Moth Bay: blastomylonitic granodiorite; carbonaceous metapelite (argillite); phyllitic siltstone, mudstone, and graywacke; phyllitic to schistose, intermediate or mafic volcanic and volcaniclastic rocks, including pillow flows and flow breccia; feather schist; granitic-clast metaconglomerate; rusty- weathering pyrite-rich felsic aplite; and marble.

Bold and Round Islands: phyllitic siltstone, graywacke, and grit; laminated andesitic(?) metatuff; cataclastic graywacke semischist; cataclastic (blastomylonitic?) granodiorite; graniticclast metaconglomerate.

Eve Point area (Thorne Arm): rusty-weathering schistose calcareous metatuff or other volcanogenic material; phyllitic to schistose siltstone, mudstone, graywacke, and intermediate or mafic volcanic or volcaniclastic rocks; massive to schistose, locally garnet-bearing and feldspar-porphyritic aphanite, aplite, and granodiorite sills and dikes; and hornblendite and pyroxenite.

Hump Island (Clover Passage): rocks assigned to this unit are locally intensely iron stained and bleached and in places contain disseminated pyrite, chalcopyrite, and possibly other sulfide minerals. Tentatively identified bedded(?) rocks include hydrothermally altered felsic or intermediate metavolcanic, volcaniclastic, or other volcanogenic rocks, and pelitic(?) metasedimentary rocks. Intrusive rock types include (a) altered garnetbearing leucocratic aplite and quartz diorite that host at least some of the disseminated sulfide minerals and (b) homblende porphyry, hornblendite, and andesite(?) dikes that apparently postdate the hydrothermal alteration

Pm Marble (Permian)-Most of this unit is light-brownweathering, massive to laminated, light-gray, 
bluish-gray, and dark gray marble. Less abundant, but locally conspicuous other lithologies mapped with it include (a) dark-green, dark-gray, or rustyweathering pyritic phyllite and semischist, (b) polymictic sedimentary breccia or conglomerate containing relict angular to subrounded clasts of basalt, marble, and felsic(?) metatuff as much as a meter long in a matrix of green metatuff and darkgray argillite, (c) schistose fragmental (volcaniclastic?) rock comprising elongate, strongly flattened relict clasts as much as several $\mathrm{cm}$ long of quartzite or felsic(?) metavolcanic rocks enclosed by rusty-weathering, fine-grained, pyrite-quartzmuscovite-mariposite(?)-calcite or -dolomite schist, and (d) greenish-black basalt dikes and sills. Thin sections of the marble typically show sugary to coarsely garnoblastic aggregates of calcite or dolomite and minor quartz, muscovite, graphite, and pyrite. Near the contacts of some plutons, the marble also contains wollastonite, diopside, and garnet. Black crinoidal marble intercalated with phyllite about $0.5 \mathrm{~km}$ south of Coon Cove contains conodonts and brachiopods of late Early Permian (Leonardian) age (Silberling and others, 1981, p. 118). Other fossil remains in the marble include numerous occurrences of locally abundant crinoid fragments (disks) of uncertain, but probably late Paleozoic, age (Berg and Cruz, 1982)

SOu Extrusive, intrusive, and sedimentary rocks, undivided (Silurian or Ordovician)-Rocks assigned to this unit, shown on the map sheet only near Caamano Point on southern Cleveland Peninsula, are more highly deformed or recrystallized correlatives of those in unit $\mathrm{SOu}$ in the Prince of Wales-Gravina-Annette-Mary-Duke Islands area (Saleeby and Gehrels, 1985; Rubin and Saleeby, 1987), which are described above. A single outcrop area of marble $(\mathrm{m})$ is large enough to show on the map sheet. It consists of tanweathering, sugary, white calcite and dolomite, intercalated with subordinate green metavolcanic and gray metasedimentary phyllite and schist. This outcrop area is about $2 \mathrm{~km}$ from an occurrence of marble too small to show on the map that is host to stibnite (antimony)-bearing veins (Berg and others, 1981, p. 62)

\section{PORTLAND PENINSULA}

Western and southwestern area

Trondhjemitic pegmatite (Tertiary or Cretaceous)This unit consists chiefly of pegmatite that contains about 70 percent sodic plagioclase, 25 percent quartz, and accessory to minor biotite, hornblende, and potassium feldspar. Some of the plagioclase, biotite, and quartz crystals are as long as $10 \mathrm{~cm}$. Outcrops typically show layers of coarse- and finegrained pegmatite that alternate with schlieren and screens of amphibolite. The unit is always adjacent to or enclosed by amphibolite ( $\mathrm{M}_{2} \mathrm{P}_{2} \mathrm{a}$ ).

We infer a Cretaceous or Tertiary emplacement age for these pegmatite bodies from their field occurrences and petrography and from available local and regional isotopic age data. A K-Ar age determination on biotite from the body on the east coast of Behm Canal, about $5 \mathrm{~km}$ north of the mouth of Smeaton Bay, gave an apparent age of about $46 \mathrm{Ma}$ (table 1, No. 39). The absence of foliation or other evidence of significant penetrative deformation in the pegmatite indicates that it was emplaced during or after the waning stages of the mid- or Late Cretaceous regional metamorphism that apparently affected most of the rocks in the Ketchikan and Prince Rupert quadrangles (see this report, discussion under Revillagigedo Island and Cleveland Peninsula: "Metamorphosed sedimentary, volcanic, and intrusive rocks (Mesozoic or Paleozoic)"; Smith and Diggles, 1981, p. 2). These relations suggest emplacement possibly as long ago as the Late Cretaceous but before about $46 \mathrm{Ma}$

Kgq Granodiorite and quartz diorite (Cretaceous)-A stock near Point Sykes consists of massive to weakly foliated, medium-grained, magmaticepidote-bearing hornblende-biotite granodiorite and quartz diorite. Mild deuteric(?) alteration includes feldspathized joints, disseminated pyrite, sericitized plagioclase, and partial recrystallization of mafic minerals to chlorite, epidote, and iron oxides. The pluton intrudes the surrounding metamorphic rocks with a sharp contact. Dikes of granodionite extend into the country rock, and the pluton is surrounded by a contact metamorphic (hornfels) aureole several hundred meters wide. The pluton is assigned a Late Cretaceous emplacement age because of discordant $\mathrm{K}-\mathrm{Ar}$ age determinations of about $59 \mathrm{Ma}$ for biotite and about $80 \mathrm{Ma}$ for hornblende (table 1, No. 53) and because of its intrusion into, and contact metamorphism of, rocks that were probably regionally metamorphosed in late Mesozoic time (see this report, discussion under Revillagigedo Island and Cleveland Peninsula: "Metamorphosed sedimentary, volcanic, and intrusive rocks (Mesozoic or Paleozoic)"; Smith and Diggles, 1981, p. 2). Two stocklike plutons of massive or slightly foliated leucocratic granodionite about $8 \mathrm{~km}$ east of the mouth of Boca de Quadra are here provisionally correlated with the pluton at Point Sykes on the basis of similarities in lithology, texture, and geologic setting

Kum Ultramafic rocks (Cretaceous)-The only occurrence of ultramafic rocks large enough to show on the map in this area is at Humpy Point. Several small, unmapped ultramafic bodies crop out along the east shore of Behm Canal south of Smeaton Bay. At Humpy Point, medium- to very coarse-grained biotite clinopyroxenite and subordinate hornblendite intrude undated gabbro (unmapped) and Silurian metamorphosed trondhjemite (Smt) with sharp contacts and no apparent thermal effects. In most outcrops, the ultramafic rocks are massive and apparently not foliated; in places, however, they contain abundant secondary chlorite. On the basis of similarities in lithology, texture, and geologic setting, this ultramafic intrusive body is correlated with the isotopically dated Cretaceous ultramafic pluton at Alava Bay

MzPza Amphibolite (Mesozoic or Paleozoic)-A linear outcrop belt of distinctive dark-greenish-black amphibolite as much as $5 \mathrm{~km}$ wide crops out from near the mouth of Rudyerd Bay to the boundary of Alaska and Canada (Berg and others, 1977, p. 13-14). The amphibolite locally is spectacularly streaked with strongly contrasting dikes, veins, and lenses of white trondhjemite pegmatite (TKp) and other leucocratic intrusive rocks. Beyond the 
boundary, the unit continues in outcrop southeastward across Sitklan Passage and into British Columbia, where it is mapped as the Work Channel Amphibolite (Hutchison, 1982, p. 11-14).

The unit commonly is strongly banded and consists of layers of greenish-black schist and gneiss that contrast strikingly with alternating layers of light-gray gneiss. The thickness of the layering varies but averages about $10 \mathrm{~cm}$. Local variation in mafic and felsic mineral content results in outcrops that vary from nearly pure hornblende schist or hornblende-biotite schist to relatively uniform darkgray gneiss containing approximately equal amounts of mafic and felsic minerals. The unit also contains minor amounts of marble, pelitic gneiss, and plagioclase-quartz-(biotite-garnet) aplite dikes. Some of the marble layers and many of the dikes are several meters thick

Thin sections of typical samples of amphibolite show fine-to medium-grained granoblastic and schistose textures; the composition averages about 45 percent plagioclase feldspar (oligoclase and andesine), 30 percent homblende, 15 percent biotite, 5 percent quartz, and 5 percent accessory minerals including apatite, clinopyroxene, garnet, magnetite, pyrite, and sphene. Retrograde minerals include small amounts of chlorite and epidote.

This amphibolite is identical in lithology and texture to the regionally metamorphosed amphibolite-facies volcanic or volcaniclastic rocks (MzPmv) that crop out on eastern Revillagigedo Island. Although the map shows thin and discontinuous outcrops of the amphibolite along the east coast of Behm Canal north of Rudyerd Bay, the main outcrop belt of amphibolite appears to strike across Behm Canal at about the latitude of Rudyerd Bay, toward the amphibolite on eastern Revillagigedo Island. On the basis of this assumed continuity, the amphibolite on Portland Peninsula is also assigned a premetamorphic age of late Paleozoic or Mesozoic. The relative proportions of metamorphosed stratified rocks and of presumably younger plutonic rocks in this map unit are unknown.

$\mathrm{K}$-Ar age determinations on metamorphic minerals from the amphibolite unit show apparent ages ranging from about $47-51 \mathrm{Ma}$ for biotite and about 50-58 Ma for hornblende (table 1, Nos. 7375). These ages probably reflect the widespread disturbance to K-Ar systems that affected most of the rocks on the Portland peninsula in middle Cenozoic time (Smith and Diggles, 1981, p. 3).

Field relations suggest gradational metamorphic and possibly compositional relations between the amphibolite unit and undivided bedded and intrusive rocks $\left(\mathrm{MzP} \mathrm{P}_{\mathrm{Z}}\right)$ on the west and between it and pelitic paragneiss ( $\left.\mathrm{M}_{2} \mathrm{P}_{\mathbf{z}}\right)$ ), foliated quartz diorite ( $\mathrm{TKfq}$ ), and foliated granodiorite (TKfg) on the east

$\mathrm{Mz} z \mathrm{U}$ Metamorphosed sedimentary, volcanic, and intrusive rocks, undivided (Mesozoic or Paleozoic)-This map unit comprises a heterogeneous, complexly deformed assemblage of originally diverse bedded and intrusive rocks that have been regionally metamorphosed to greenschist and possibly amphibolite facies and locally remetamorphosed during emplacement of some plutons. Most of the rocks in the assemblage are green or silvery-gray schists that, depending on original composition and proximity to plutons, contain varying proportions of quartz, plagioclase, chlorite, epidote-clinozoisite, biotite, muscovite, actinolite or hornblende, garnet, kyanite, and calcite. Locally prominent rock types àlso include feather schist, rusty-weathering quartzmuscovite schist possibly derived from felsic volcanic or volcanic-related rocks, quartzite, ultramafic rocks, marble, and sheared intrusive rocks apparently originally granodiorite, trondhjemite, quartz diorite, and diorite. Outcrop areas of marble $(\mathrm{m})$ large enough to show on the map are present locally. The marble appears massive to platy, is white, gray, and bluish gray, and weathers light brown. It consists of a sugary to coarse-grained aggregate of calcite or dolomite and has subordinate to minor amounts of muscovite, phlogopite, quartz, graphite, garnet, and pyrite. Although we were not able to subdivide this assemblage on Portland peninsula, its lithology and structural and metamorphic features apparently are identical with those of most of the metamorphosed bedded and intrusive rocks (MzPu, MzZzms, MzPmv, MzPmi) mapped on southern Revillagigedo Island. A few objects doubtfully identified as crinoid remnants (disks) that occur in the marble $(\mathrm{m})$ at Very Inlet (Berg and Cruz, 1982) suggest possible correlation with the Permian crinoidal marble on Revillagigedo Island.

$\mathrm{K}$-Ar determinations on metamorphic minerals in two samples of schistose bedded rocks from this unit show apparent ages ranging from about 47 to $69 \mathrm{Ma}$ for biotite, and 61 to $77 \mathrm{Ma}$ for homblende (table 1, Nos. 70-72); actinolite from a sheared and recrystallized mafic dike gave an apparent age of about $86 \mathrm{Ma}$ (No. 72). Regional geologic relations suggest that at least some of the rocks have undergone (a) the mid- or Late Cretaceous regional metamorphism that apparently affected most of the rocks in the study area (this report, discussion under Revillagigedo Island and Cleveland Peninsula area: "Metamorphosed sedimentary, volcanic, and intrusive rocks (Mesozoic or Paleozoic)"; Smith and Diggles, 1981, p. 2), (b) thermal metamorphism related to the emplacement of the Cretaceous granodionite (Kgq) stock near Point Sykes, and (c) the widespread disturbance to K-Ar systems in rocks older than $\mathbf{4 0}$ $\mathrm{Ma}$ that affected most of Portland peninsula in middle Cenozoic time (Smith and Diggles, 1981, p. 3). Quartz veins and lenses in the green or gray schist have been prospected for gold, and the rusty-weathering schist locally contains deposits of disseminated and massive sulfides that have been prospected for gold, silver, copper, and zinc (Berg and others, 1981, p. 66)

Smt Metamorphosed trondhjemite (Silurian)-The Cape Fox pluton (Koch and others, 1977) is an elongate $(9 \mathrm{~km} \times 23 \mathrm{~km})$ stock of regionally metamorphosed trondhjemite exposed at the southwest tip of Portland peninsula. The pluton originally crystallized as leucocratic coarse-grained hypidiomorphic-granular trondhjemite. Extensive recrystallization has reduced almost all the primary 
biotite to chlorite. Most outcrops contain abundant metamorphic epidote. Pervasive fracturing and shearing increase outward from the core of the pluton. Parts of the pluton, especially toward the north, have been reduced to quartzofeldspathic semischist and schist that are difficult to distinguish from the enclosing schistose country rock. At least some of the metamorphism probably coincided with the regional metamorphism that apparently affected most of the rocks in neighboring areas in mid- or Late Cretaceous time (this report, discussion under Revillagigedo Island and Cleveland Peninsula: "Metamorphosed sedimentary, volcanic, and intrusive rocks (Mesozoic or Paleozoic)"). The pluton is assigned a Silurian emplacement age on the basis of a preliminary $\mathrm{Pb}$ $\mathrm{U}$ (zircon) age determination of about $428 \mathrm{Ma}$ (table 1, No. 83)

SOu Extrusive, intrusive, and sedimentary rocks, undivided (Silurian or Ordovician)-Rocks assigned to this unit are here interpreted as the more highly deformed or recrystallized correlatives of those in unit SOu in the Prince of WalesGravina-Annette-Mary-Duke Islands area, which are described above

\section{Central and eastern area}

Four stocklike plutons (Tqm, Tgb, Tgp), aligned along a nearly linear eastward trend in central Portland peninsula, yield radiometric ages ranging from late Oligocene to middle Miocene. Despite their near-contemporaneity and relative proximity, the plutons differ markedly in composition and texture. The stocks intrude various metamorphic and plutonic rocks with minor contact effects, and are cut by lamprophyre dikes (Smith, 1973) that are too small to show on our map:

Tqm Biotite quartz monzonite (Tertiary)-This pluton consists of massive, medium- to coarse-grained, hypidiomorphic granular, locally miarolitic quartz monzonite that contains sparse phenocrysts of pale-pink potassium feldspar as long as $1.5 \mathrm{~cm}$. Thin-section examination of typical samples shows (a) subhedral to euhedral crystals of twinned and concentrically zoned plagioclase whose cores commonly contain minute grains of epidote, white mica, and opaque minerals, (b) interstitial quartz and discrete anhedral crystals of quartz, (c) as much as 7 percent of subhedral to euhedral brown biotite, (d) a percent or two of euhedral green hornblende, and (e) traces of sphene. Some of the mafic minerals are altered to chlorite. We assign this pluton an Oligocene or Miocene emplacement age on the basis of $\mathrm{K}$-Ar age determinations of 22.9 Ma for biotite and 26.8 Ma for hornblende, and on $\mathrm{Pb}-\mathrm{U}$ (zircon) age determinations of about $19 \mathrm{Ma}$ (table 1, No. 6)

Tgb Gabbro (Tertiary)-This roughly circular stock consists chiefly of uniform, predominantly subophitic finegrained gabbro containing labradorite and later oligoclase, augite, biotite, hypersthene, green and brown homblende, magnetite, apatite, and locally olivine. Field and thin-section studies suggest that the stock may be concentrically zoned (Berg and others, 1977, p. 24-25). Except for minor granulation and for slight alteration of mafic minerals to chlorite, prehnite(?), and bastite serpentine, the gabbro is undeformed and fresh. We assign the pluton an emplacement age of
Oligocene or Miocene on the basis of a $\mathrm{K}$-Ar age determination on biotite of $23.8 \mathrm{Ma}$ (table 1 , No. 4)

Tgp Granite and granite porphyry (Tertiary)-This unit (Elliott and others, 1976, p. 9-11; Hudson and others, 1979) consists of two roughly oval composite felsic stocks and a suite of related quartz- and feldspar-porphyritic felsic dikes that are too small show on the map. The dikes occur in a belt $5 \mathrm{~km}$ wide that extends east-northeastward at least $20 \mathrm{~km}$ from Wilson Arm to and beyond the stocks. The stocks contain several textural varieties of biotite granite and granite porphyry, and they show no evidence of regional penetrative deformation. Typical samples of the granite consist of light-gray, fine- to medium-grained, hypidiomorphic granular biotite granite containing scattered phenocrysts up to $1 \mathrm{~cm}$ long of pinkishgray perthite and subhedral to euhedral gray quartz. In general, the porphyry consists of felsic aplite that contains sparse to abundant euhedral phenocrysts as long as $1 \mathrm{~cm}$ of brown biotite, sodic plagioclase, perthite, and quartz. Some of the porphyry contains quartz-, muscovite-, and pyritelined miarolitic cavities as much as $2 \mathrm{~mm}$ in diameter. Much of the granite and porphyry in the smaller stock is intensely argillized and silicified and cut by networks of thin quartz-molybdenite veins and molybdenite-coated fractures. This porphyry molybdenum deposit was being developed (in 1987) by private interests. We assign this unit an Oligocene emplacement age on the basis of $\mathrm{K}-\mathrm{Ar}$ age determinations on biotite ranging from 26.9 to $30.4 \mathrm{Ma}$ (table 1, Nos. 8, 9), and a $\mathrm{Pb}-\mathrm{U}$ (zircon) age determination of $31 \mathrm{Ma}$ (table 1, unnumbered sample). The contacts between the stocks and the country rocks of paragneiss $\left(\mathrm{MzP}_{2} \mathrm{p}\right)$ and gneissic granodiorite ( $\mathrm{TKfg}$ ) are locally marked by narrow thermal aureoles

Three plutonic rock units (Tgq, Tdr, Tg) of up to batholithic dimensions have isotopically determined or inferred Eocene emplacement ages. Two of them are on eastern Portland peninsula, and continue eastward beyond Portland Canal into British Columbia (Hutchison, 1982). The plutons are complexly jointed and locally cut by faults and shear zones, but they show no evidence of penetrative deformation or regional metamorphism. They range in texture from massive to foliated or even locally gneissic. Some of these planar and linear textures may be the result of local deformation, but we interpret them to be due mainly to alignment of mafic inclusions and minerals during emplacement of the plutons or to partial assimilation of more foliated or gneissic country rocks. All of the plutons are intruded by numerous lamprophyre dikes too small to show on the map:

Tgq Granodiorite and quartz monzonite (Tertiary)-As mapped, this unit includes the batholith composed of the Hyder Quartz Monzonite (Buddington, 1929 , p. 29-32; Smith, 1977, p. 32-37) and correlative plutons (Berg and others, 1977, p. 22 23) that occur in north-central and northeastern Portland peninsula, and a stock at Fitzgibbon Cove on the west coast of northernmost Portland peninsula. The stock at Fitzgibbon Cove is the only (inferred) Eocene pluton mapped on the western part of the peninsula. The Hyder Quartz Monzonite and its correlatives on northeastern Portland 
peninsula consist mainly of massive to weakly foliated granodiorite and quartz monzonite; the map unit also encompasses outcrops of paragneiss, dikes, and other intrusive rocks too small to show on the map. Typical specimens of the Hyder Quartz Monzonite are medium grained and hypidiomorphic granular, and their average mineral composition is plagioclase (45 percent), potassium feldspar ( 23 percent), quartz ( 22 percent), biotite $(6$ percent), and hornblende (4 percent); the most prominent accessory mineral is sphene, which occurs as golden-yellow euhedra as large as $5 \mathrm{~mm}$. Outcrops of the Hyder Quartz Monzonite commonly contain aplite and felsic pegmatite dikes. The Eocene emplacement age of the Hyder Quartz Monzonite is based on concordant hornblende and biotite K-Ar dates of about $50 \mathrm{Ma}$ (table 1, Nos. 10-13). The contacts of the Hyder Quartz Monzonite with most other map units generally are sharp and free of significant thermal or other contact effects. Its contact with foliated granodiorite of unit $\mathrm{TKfg}$, however, is locally difficult to map because of compositional and textural similiarities between the two units.

The stock at Fitzgibbon Cove consists of fine- to medium-grained leucocratic biotite-hornblende granodiorite and minor quartz monzonite. It typically is hypidiomorphic granular but locally contains a few percent of euhedral potassium feldspar phenocrysts as long as about $1 \mathrm{~cm}$. Accessory minerals include sphene, zircon, apatite, magnetite, pyrite, and allanite. Outcrops generally appear massive and of uniform composition. Small inclusions of fine-grained mafic rock occur near some contacts, and locally well-developed compositional layering and cross laminations suggest settling and flow of mafic and other crystals before solidification of the magma. The stock intrudes several metamorphic and plutonic rocks, including Late Cretaceous or Paleocene foliated quartz diorite (TKfq). We infer an Eocene emplacement age because this body closely resembles the Hyder Quartz Monzonite in composition and texture and because it lacks any of the distinctive features (such as miarolitic or strongly porphyritic textures) of the Oligocene or Miocene felsic plutons. Intrusive contacts of the stock with other units generally are sharp and free of significant thermal or other contact effects

Tdr Davis River pluton (Tertiary)-This pluton consists of porphyritic coarse-grained homogeneous biotitehornblende granodiorite that locally grades into quartz dionite and quartz monzonite (Smith, 1977, p. 28-32). It typically contains about 5 percent of euhedral phenocrysts of potassium feldspar as large as $5 \mathrm{~cm}$. The texture of the groundmass is hypidiomorphic granular, and the mafic minerals are interstitial to and finer grained than the felsic minerals. Approximate average composition of the pluton is plagioclase ( 50 percent), quartz (25 percent), potassium feldspar (15 percent), and mafic minerals (10 percent). The Davis River pluton intrudes several plutonic and metamorphic rocks without significant contact effects and is in turn intruded by the Hyder Quartz Monzonite. The Eocene emplacement age of the Davis River pluton is based on $\mathrm{K}$-Ar age determinations on biotite ranging from 43.0 to $46.8 \mathrm{Ma}$, and on hornblende ranging from 48.9 to $55.0 \mathrm{Ma}$ (table 1 , Nos. 14 17)

Tg Granodiorite (Tertiary)-This pluton consists mainly of weakly foliated to massive, medium-grained hornblende-biotite granodiorite, and locally of foliated and gneissic granodionite. Our field examinations of this pluton suggest that its inland outcrops are more massive appearing and less gneissic than its exposures along Portland Canal. This apparent difference may be due to differences in weathering and erosion or to differences in composition and texture within the pluton. Foliation, where present, is expressed by layers that have different total mafic contents and by sparse schlieren. Mafic minerals generally make up 15 to 25 percent of this pluton. Hornblende is predominant in its southern part; biotite generally equals or locally exceeds hornblende in most of its northern part. Euhedral phenocrysts of potassium feldspar as large as $2 \mathrm{~cm}$ are present in many areas but are rarely abundant. The pluton intrudes paragneiss (MzPz) and is intruded by Eocene granodionite and quartz monzonite (Tgq). It also intrudes foliated granodiorite of unit $\mathrm{TKfg}$, but this contact locally is difficult to map because these two units are similar in composition and texture. The pluton is assigned an Eocene emplacement age on the basis of K-Ar age determinations of 43.1 and $45.0 \mathrm{Ma}$ for biotite and of 49.6 and $51.5 \mathrm{Ma}$ for hornblende (table 1, Nos. 18-19). If this pluton continues in outcrop eastward across Portland Canal into British Columbia, it may correlate in part with the Ponder pluton (Hutchison, 1982)

TKfq Foliated quartz diorite (Tertiary or Cretaceous)Stocklike and elongate plutons of quartz diorite, locally accompanied by minor amounts of other rocks, form a discontinuous belt about $10 \mathrm{~km}$ wide along and near east Behm Canal. Scattered outlying bodies 15 to $25 \mathrm{~km}$ from the canal are aligned roughly parallel to the main belt (Berg and others, 1977, p. 18-19). About 60 percent of the unit is dark-gray-weathering, uniformly foliated to gneissic quartz diorite; the rest consists of paragneiss (21 percent), granodiorite (11 percent), and subordinate migmatite, amphibolite, pegmatite, and quartz monzonite. The quartz diorite commonly is at least weakly foliated. Planar fabric varies from a faint alignment of mafic minerals to marked gneissic banding. The general trend of this gneissic structure is shown on the map by a dashed pattern. This foliation generally strikes north or northwest, parallel to the regional outcrop trend and to the internal structure of the adjoining metamorphosed bedded ( $\mathrm{Mz}_{2} \mathrm{zp}, \mathrm{MzP}_{2} \mathrm{a}$ ) and intrusive (TKfg) rocks. Thin sections of typical samples of quartz dionite show medium-grained, granular to planar aggregates of andesine (54 percent), quartz (18 percent), hornblende (13 percent), biotite (12 percent), and accessory apatite, augite, garnet, magnetite, muscovite, potassium feldspar, and sphene. Small amounts of epidote, chlorite, and saussurite record slight, but widespread postemplacement alteration. Much of the unit also shows cataclastic textures such as undulatory quartz and incipient granulation along grain boundaries. The mineralogy and texture 
indicate that the planar fabric probably resulted mainly from mineral alignment during emplacement of the plutons, whereas the incipient cataclasis and generally concordant structural relations suggest that their emplacement took place during the waning stages of regional deformation. Contacts between the quartz diorite plutons and the paragneiss (MzPs) and foliated granodiorite (TKfg) units are largely inferred from the regional distribution of the major rock types. The unit is intruded by Oligocene or Miocene gabbro and by (inferred) Eocene quartz monzonite.

The unit is assigned an emplacement age of Late Cretaceous or Paleocene on the basis of $\mathrm{Pb}-\mathrm{U}$ (zircon) age determinations of about $55 \mathrm{Ma}$ (table 1, Nos. 22, 23) and 58 Ma (G.E. Gehrels, oral commun., 1983) for samples collected on Portland peninsula, and of about 64-67 Ma in correlative rocks near Juneau (Gehrels and others, 1983a).

$\mathrm{K}$-Ar radiometric studies on samples of quartz diorite frm Portland peninsula show apparent ages of 45.6-47.5 Ma for biotite and 47.6-55.7 Ma for hornblende (table 1, Nos. 20, 21, 23, 24). These data probably reflect an event that strongly disturbed K-Ar systems in rocks older than $40 \mathrm{Ma}$ throughout much of the study area (this report, discussion under Revillagigedo Island and Cleveland Peninsula: "Metamorphosed sedimentary, volcanic, and intrusive rocks (Mesozoic or Paleozoic)"; Smith and Diggles, 1981, p. 3).

The quartz diorite pluton at the south end of Portland peninsula continues in outcrop southward across Pearse Canal into British Columbia, where it is mapped as the Quottoon pluton (Hutchison, 1982)

TKfg Foliated granodiorite (Tertiary or Cretaceous)-This unit (Berg and others, 1977, p. 19-22) is an assemblage mostly of metamorphosed plutonic rocks that we were unable to subdivide during our largely reconnaissance-scale geologic investigations of Portland peninsula. More detailed mapping, for example, probably would reveal several distinct plutons, possibly of different emplacement ages. As mapped, the unit consists mostly of foliated and gneissic granodiorite, but it also contains a wide variety of other rock types. Based on samples collected, the unit consists mainly of granodiorite (51 percent), quartz monzonite (14 percent), and quartz diorite (13 percent), but locally includes such nonintrusive components as hornfels, marble, paragneiss, and gneiss of undetermined origin (18 percent). About 2 percent of the unit is migmatite, the most prominent outcrop areas of which are shown by a pattern on the map. The remaining 2 percent includes aplite, diorite, granite, hornblendite, lamprophyre, and one occurrence of pyroxenite. The average of 50 modal (point count) analyses of medium-grained foliated and gneissic granodiorite typical of the unit shows 50 percent plagioclase (oligocene and andesine), 20 percent quartz, 15 percent potassium feldspar, 8 percent hornblende, and 7 percent biotite. The rock commonly also contains less than one percent of one or more of the accessory minerals apatite, garnet, muscovite, pyrite, and sphene. Widespread incipient retrograde metamorphism has produced traces of albite(?), chlorite, epidote, and sericite.

Much of the granodiorite is distinguished by euhedral crystals of potassium feldspar as long as $2.5 \mathrm{~cm}$. The crystals contrast markedly in size with the other minerals, and they weather in relief.

The contacts between the foliated granodiorite unit and adjacent units are drawn mainly on the basis of the regional distribution of the major rock types. The regional map patterns and local contact relations show that the unit is intruded by the Eocene ( $\mathrm{Tgq}, \mathrm{Tdr}, \mathrm{Tg}$ ) as well as the Oligocene (Tgp) and Oligocene or Miocene (Tgb) plutons, and that it may locally be gradational with the paragneiss $\left(\mathrm{MzP}_{2} \mathrm{p}\right)$, foliated quartz diorite (TKfq), and foliated quartz monzonite $(\mathrm{Kfq})$ units. Geologic relations also indicate that it underlies most of the paragneiss unit on central Portland peninsula.

The Cretaceous or Tertiary age assignment of this unit reflects our concept of it as an assemblage primarily of metamorphosed plutonic rocks possibly having more than one emplacement age. This assigned range of possible emplacement ages is based partly on a preliminary $\mathrm{Pb}-\mathrm{U}$ (zircon) age determination of about $140 \mathrm{Ma}$ (Early Cretaceous) (table 1, No. 38) on a sample of plutonic rock in the Boca de Quadra area and partly on the likelihood that it contains unmapped intrusive rocks correlative with, but indistinguishable from, the Cretaceous foliated quartz monzonite and granodionite $(\mathrm{Kfq})$ and Cretaceous or Tertiary foliated quartz diorite (TKfq) units. The unit may also encompass unmapped outcrops of Eocene or younger plutonic rocks or of various metamorphosed bedded rocks.

Numerous samples of foliated plutonic rocks from the unit yield $\mathrm{K}-\mathrm{Ar}$ apparent ages ranging from about 43 to $50 \mathrm{Ma}$ for biotite and 48 to 59 Ma for hornblende (table 1, Nos. 26-37). Some of these ages may date the emplacement of part of the unit, but they most probably reflect the event that strongly disturbed K-Ar systems in rocks older than $40 \mathrm{Ma}$ in the study area (this report, discussion under Revillagigedo Island and Cleveland Peninsula: "Metamorphosed sedimentary, volcanic, and intrusive rocks (Mesozoic or Paleozoic)"; Smith and Diggles, 1981, p. 3).

Kfq Foliated quartz monzonite and granodiorite (Cretaceous)-This heterogeneous pluton consists chiefly of foliated leucocratic quartz monzonite and granodiorite, but it also includes significant amounts of granodiorite and quartz monzonite gneiss, and migmatite. The pluton is characterized by large changes in texture and composition over short distances. Schlieren are common throughout, and layered xenoliths of amphibolite and paragneiss are present in many areas. Foliation in the plutonic rocks is defined by layers of different grain size and mafic mineral content. Mafic minerals generally make up less than 10 percent of the pluton: fine-grained biotite is more abundant than hornblende in its southern part; hornblende is more common in the north. The pluton intrudes paragneiss $\left(\mathrm{M}_{2} \mathrm{P}_{2} \mathrm{p}\right)$ and in turn is intruded by Eocene plutons ( $\mathrm{Tdr}, \mathrm{Tg})$. Its contact with the foliated granodiorite unit (TKfg) is difficult to map phyllite, and fine-grained recrystallized limestone 
because of similarities in composition and textures between these two units. The pluton is assigned a Cretaceous emplacement age based on preliminary $\mathrm{Pb}-\mathrm{U}$ (zircon) age determinations of 99 and 116 Ma (table 1, No. 54). K-Ar apparent ages of 41.2 $\mathrm{Ma}$ on biotite, and $51.2 \mathrm{Ma}$ on hornblende probably reflect an event that strongly disturbed KAr systems in rocks older than $40 \mathrm{Ma}$ throughout much of the study area (this report, discussion under Revillagigedo Island and Cleveland Peninsula: "Metamorphosed sedimentary, volcanic, and intrusive rocks (Mesozoic or Paleozoic)"; Smith and Diggles, 1981, p. 3)

MzPp Paragneiss (Mesozoic or Paleozoic)-This unit (Berg and others, 1977, p. 12-13) is characterized by rusty-brown-weathering pelitic paragneiss and schist containing conspicuous rootbeer-brown biotite and by subordinate quartzofeldspathic gneiss distinguished mainly by its light color and low content of mafic minerals.. Such rocks make up about 66 percent of the unit. The remainder, based on the number of samples of different rock types collected, includes migmatite (16 percent), gneissic plutonic rocks ( 7 percent), marble and calcsilicate gneiss (4 percent), pegmatite (3 percent), quartzite ( 2 percent), amphibolite (1 percent), and aplite (1 percent). A single rock type may underlie wide areas, or several different rock types may be interlayered across a short distance; the latter probably represents a fragment of premetamorphic stratigraphy. The unit has been complexly folded and was probably recrystallized more than once. More than one set of mesoscopic structures is present at most outcrops.

The paragneiss typically consists of alternating light-gray, dark-gray, or medium-brown layers, averaging $1-10 \mathrm{~cm}$ in thickness and containing about 50 percent oligoclase and andesine, 25 percent quartz, and 15 percent biotite. Up to about 10 percent accessory minerals include potassium feldspar, garnet, sillimanite, and muscovite. The paragneiss commonly also contains traces of one or more of the following minerals: apatite, clinopyroxene, cordierite, orthopyroxene, graphite, hornblende, magnetite, pyrite, sphene, and zircon. This metamorphic mineral assemblage indicates widespread amphibolite- and possibly locally granulite- facies regional metamorphism (Turner, 1981, p. 366-407; Hollister, 1975; Selverstone and Hollister, 1980). Secondary minerals, the results of widespread incipient retrograde metamorphism, include small amounts of actinolite, albite(?), chlorite, epidote, and sericite.

In many places, the paragneiss grades imperceptibly downward and laterally into gneissic granodiorite (TKfg). Elsewhere, it is in sharp contact with plutonic rocks or passes gradually into them through a zone of migmatite. The contact between the paragneiss and the amphibolite unit ( $\left.\mathrm{Mz} \mathrm{P}_{2} \mathrm{a}\right)$ generally is a zone as wide as $10 \mathrm{~m}$ of a transitional rock type containing approximately equal amounts of biotite and hornblende.

The minerals and textures of the schist and gneiss and the intercalated layers of marble indicate that the metasedimentary protoliths of the paragneiss sequence were deposited in a marine environment and consisted of argillaceous clastic sediments and minor amounts of limestone, chert(?), and felsic to intermediate or mafic volcanic or volcaniclastic rocks. The ages of these protoliths have not been conclusively determined by isotopic methods. We infer the Paleozoic or Mesozoic age assignment for this unit from (a) studies of correlative rocks nearby in British Columbia, where geologic relations and isotopic age determinations suggest pre-Permian, older Paleozoic, and Precambrian ages (Hutchison, 1982, p. 23-24), and (b) our assumption that some of the pelitic paragneiss may correlate with the amphibolite facies upper Paleozoic or Mesozoic metasedimentary rocks ( $\mathrm{Mz}_{\mathrm{z}} \mathrm{ms}$ ) on eastern Revillagigedo Island. K-Ar dating studies of several variants of the paragneiss on Portland peninsula give apparent ages of 42.9-46.8 Ma for biotite and 47.0-57.0 Ma for hornblende (table 1, Nos. 7680 ). At least one of the metamorphic events that affected the unit probably occurred during this interval, but these ages probably reflect the regional disturbance to $\mathrm{K}-\mathrm{Ar}$ systems in rocks older than $40 \mathrm{Ma}$ in the study area (this report, discussion under Revillagigedo Island and Cleveland Peninsula: "Metamorphosed sedimentary, volcanic, and intrusive rocks (Mesozoic or Paleozoic)"; Smith and Diggles, 1981, p. 3)

Northeastern area

kt Texas Creek Granodionite (Triassic)-The Texas Creek Granodionite that crops out at the northeast corner of the Ketchikan quadrangle is the southwesternmost part of a batholith that crops out mainly in Alaska north of the quadrangle and in neighboring parts of British Columbia (Buddington, 1929 , p. 22-29; Grove, 1971, p. 60-62; Smith, 1977, p. 16-24; and Berg and others, 1977, p. 17-18). The pluton consists mainly of recrystallized, locally cataclastically deformed granodiorite and minor quartz diorite. Hand specimens are typically greasy green with cloudy feldspars and indistinct grain boundaries. Representative thin sections show a mediumgrained hypidiomorphic granular aggregate of (a) essential andesine or oligoclase, quartz, and potassium feldspar, (b) accessory sphene, green homblende, and green biotite, and (c) secondary albite, muscovite, clinozoisite-epidote, actinolite, chlorite, calcite, and opaque minerals. In many specimens, euhedral crystals of potassium feldspar and hornblende as long as $2 \mathrm{~cm}$ impart a distinct and characteristic porphyritic texture.

In general, the Texas Creek Granodiorite is relatively massive and lacks pronounced primary or metamorphic foliation. Instead, parts of it are characterized by cataclastic textures. The intensity of the cataclasis generally is low, but locally the granodiorite is converted to mylonite. In addition to widespread incipient cataclasis, the pluton was affected by low-grade regional metamorphism and by thermal metamorphism to hornblende-hornfels facies. The regional metamorphism partly obliterated original textures and produced mineral assemblages typical of the greenschist facies. The regional metamorphism and the cataclasis predate the intrusion of the Eocene plutons, which 
produced thermal aureoles as wide as $2 \mathrm{~km}$ along their contacts with the batholith

The Texas Creek Granodiorite intrudes recrystallized upper Paleozoic or Mesozoic bedded rocks ( $\mathrm{M}_{2} \mathrm{P}_{2} v \mathrm{~s}$ ) and in turn is cut by Eocene granodionite and quartz monzonite (Tgq).

The Texas Creek Granodiorite is here assigned a Triassic emplacement age on the basis of apparent K-Ar hornblende ages of 203 and $211 \mathrm{Ma}$, which are considered likely to be minimum ages of emplacement (Smith and Diggles, 1981, p. 2)

MzPzvs Recrystallized volcanic and sedimentary rocks (Mesozoic or Paleozoic)-The northeasternmost corner of the Ketchikan quadrangle is underlain by a sequence of recrystallized andesitic volcanic and volcaniclastic rocks, flysch, and minor limestone (Smith, 1977, p. 9-14; Berg and others, 1977, p. 15-17). The sequence extends eastward into British Columbia (Grove, 1971, p. 38-48) and crops out discontinuously northwestward along the Alaska-Canada boundary (R.L. Elliott and R.D. Koch, unpub. data, 1979). The dominant rocks in the sequence are interbedded andesitic tuff breccia, volcanic graywacke, and siltstone and argillite; less common rocks include coarse volcanic conglomerate, possibly broken-pillow breccia, and dark-blue-gray marble.

The tuff breccia is massive and commonly in beds $0.5-4.0 \mathrm{~m}$ thick. Representative samples contain 5-50 percent poorly sorted angular to subrounded, slightly vesicular lapilli, set in an unsorted and unstratified volcanic graywacke matrix. Phenocrysts of euhedral, zoned plagioclase 1-10 mm long constitute 5-20 percent of the lapilli. They have largely recrystallized to albite or oligoclase and clinozoisite-epidote, but those that survive recrystallization retain their original andesine composition. Phenocrysts of mafic minerals are much less common than those of plagioclase, and most lapilli contain no mafic phenocrysts. The mafic minerals are strongly pleochroic, euhedral, green or brown hornblende and subordinate colorless subcalcic augite. Most mafic phenocrysts have recrystallized to masses of actinolite, chlorite, and opaque minerals. The groundmass of the lapilli is mostly a recrystallized aphanitic aggregate of albite, quartz, chlorite, epidote, and opaque minerals; shapes suggestive of microlites are still visible in some specimens. The graywacke matrix of the tuff breccia consists of sand-sized, angular mineral fragments identical to the phenocrysts in the lapilli and a pasty (palagonite?) filling.

The sequence is characterized by low greenschist-facies mineral assemblages, but is generally not schistose or otherwise penetratively deformed. Locally it also is contact metamorphosed by the intrusion of the Texas Creek Granodionite ( $\mathrm{kt}$ ) and Eocene (Tgq) plutons. In some places, the strata are tightly to isoclinally folded with steep axial planes; in other places they are deformed into nearly recumbent folds with gently to moderately northeastward dipping axial planes. Berg and others (1977, p. 29) postulate a zone of large-scale overthrusting, parallel to the semirecumbent structures, that is intruded by the Eocene plutons (map sheet, section $A-A^{\prime}$ ).

Neither the stratigraphic base nor the top of the sequence is exposed in the study area; its minimum structural thickness, on the basis of cliff exposures, is about $750 \mathrm{~m}$; immediately north of the Ketchikan quadrangle, the sequence forms the erosional remnants of an arched roof over the Texas Creek Granodiorite (Smith, 1977, p. 10).

We found no fossils in this sequence in the Ketchikan quadrangle. Its assigned stratigraphic age of late Paleozoic or Mesozoic is based partly on Permian fossils collected from limestone in a probably correlative sequence in Alaska at Mount Whipple on the Alaska-Canada boundary about $120 \mathrm{~km}$ northwest of the Ketchikan quadrangle (R.L. Elliott, unpub. data, 1979), and partly on geologic evidence near Hyder that indicates gradational, probably cogenetic relations between the Texas Creek Granodiorite and some of the volcanic rocks in this sequence (H.C. Berg and R.L. Elliott, unpub. field data, 1973) 
